\title{
Mechanisms controlling hormone secretion in human gut and its relevance to metabolism
}

\author{
Alyce M Martin1,*, Emily W Sun ${ }^{1, *}$ and Damien J Keating1,2 \\ ${ }^{1}$ College of Medicine and Public Health, Flinders University, Adelaide, South Australia, Australia \\ 2Nutrition and Metabolism, South Australian Health and Medical Research Institute, Adelaide, South Australia, Australia \\ Correspondence should be addressed to D J Keating: Damien.keating@flinders.edu.au \\ *(A M Martin and E W Sun contributed equally to this work)
}

\begin{abstract}
The homoeostatic regulation of metabolism is highly complex and involves multiple inputs from both the nervous and endocrine systems. The gut is the largest endocrine organ in our body and synthesises and secretes over 20 different hormones from enteroendocrine cells that are dispersed throughout the gut epithelium. These hormones include GLP-1, PYY, GIP, serotonin, and CCK, each of which play pivotal roles in maintaining energy balance and glucose homeostasis. Some are now the basis of several clinically used glucose-lowering and weight loss therapies. The environment in which these enteroendocrine cells exist is also complex, as they are exposed to numerous physiological inputs including ingested nutrients, circulating factors and metabolites produced from neighbouring gut microbiome. In this review, we examine the diverse means by which gut-derived hormones carry out their metabolic functions through their interactions with different metabolically important organs including the liver, pancreas, adipose tissue and brain. Furthermore, we discuss how nutrients and microbial metabolites affect gut hormone secretion and the mechanisms underlying these interactions.
\end{abstract}

Key Words
- GLP-1
- PYY
- serotonin
- CCK
- GIP
- obesity
- diabetes
- microbiome
- liver
- pancreas
- adipose tissue

\section{Introduction}

Enteroendocrine (EE) cells are specialised hormonesecreting cells that are dispersed throughout the mucosal epithelial layer of the gastrointestinal (GI) tract. Collectively, these cells constitute $1 \%$ of the mucosal cell population and are, by mass, the largest endocrine tissue in the body (Ahlman \& Nilsson 2001). EE cells consist of an array of different cell types, synthesising and secreting a combination of more than 20 hormones in response to a variety of luminal and basolateral stimuli. The characterisation of distinct EE cell types has been traditionally based on their dominant and supposedly unique hormone expression profile, such as enterochromaffin (EC) cells secreting serotonin (5-HT),
L cells secreting glucagon-like peptide 1 (GLP-1), peptide YY (PYY) and oxyntomodulin (OXM), and glucosedependent insulinotropic peptide (GIP) secreting K cells. It is now clear that such a classification system is not accurate given the accumulation of evidence that crossover in hormone co-expression exists in a regionally distinct manner, giving rise to an array of EE cell subtypes (Fothergill et al. 2017).

Gut-derived hormones influence a range of physiological processes, including metabolic pathways. They perform these regulatory roles in glucose homeostasis, centrally-mediated appetite control and adiposity. This review focuses on the molecular mechanisms driving gut

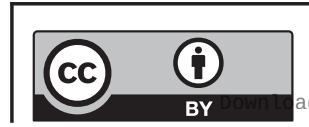

This work is licensed under a Creative Commons Attribution 4.0 International License. 
hormone secretion and describes how this is significant in the context of human metabolism and the pathogenesis of human metabolic disorders.

\section{Gut hormone regulation of metabolism}

The regulation of whole-body metabolism involves the integrated activity of multiple metabolically active tissues, including the GI tract, pancreas, adipose tissue, liver and the central nervous system (CNS). The release of one or a combination of gut hormones either postprandially (GLP-1, GIP, PYY, 5-HT, CCK, OXM) or during periods of fasting (ghrelin, 5-HT) significantly influences both glucose homeostasis and overall energy status. Each of these hormones can exert such effects independently or can act in a synergistic manner to influence these processes (Fig. 1).

\section{Glucose homeostasis}

The coordinated control of endogenous glucose output and the clearance of exogenous glucose is required to maintain blood glucose homeostasis. If not adequately controlled, this can lead to metabolic diseases such as type 2 diabetes (T2D) and markedly increased cardiovascular risk.
Hepatic glucose production is the primary determinant of glucose homeostasis and is predominantly dictated by pancreatic insulin and glucagon. In addition, postprandial glucose disposal by other insulin-sensitive tissues such as skeletal muscles and adipose tissue, and exogenous glucose uptake by the intestine also significantly determines peripheral glucose levels. In particular, the distal small intestine has been shown to contribute to gastrointestinal-mediated glucose disposal in both healthy and type 2 diabetic humans and coincides with incretin hormone release (Zhang et al. 2019). Gut hormones have well-established glucoregulatory roles, via activation of receptors expressed by target tissues.

\section{Endocrine pancreas}

Dysregulated secretion of insulin and glucagon, the two primary islet hormones, is a major contributing factor of the development of diabetes mellitus. Although a number of gut-derived hormones augment glucose-stimulated insulin secretion (GSIS) from pancreatic $\beta$ cells and expansion of $\beta$-cell mass, some of these including GLP-1, GIP, CCK, PYY and 5-HT, have also been identified in the pancreas (Fujita et al. 2010). As such, the relative contributions of islet- and gut-derived hormones to pancreatic function have been increasingly scrutinised. It was originally thought that enteroendocrine L cells and

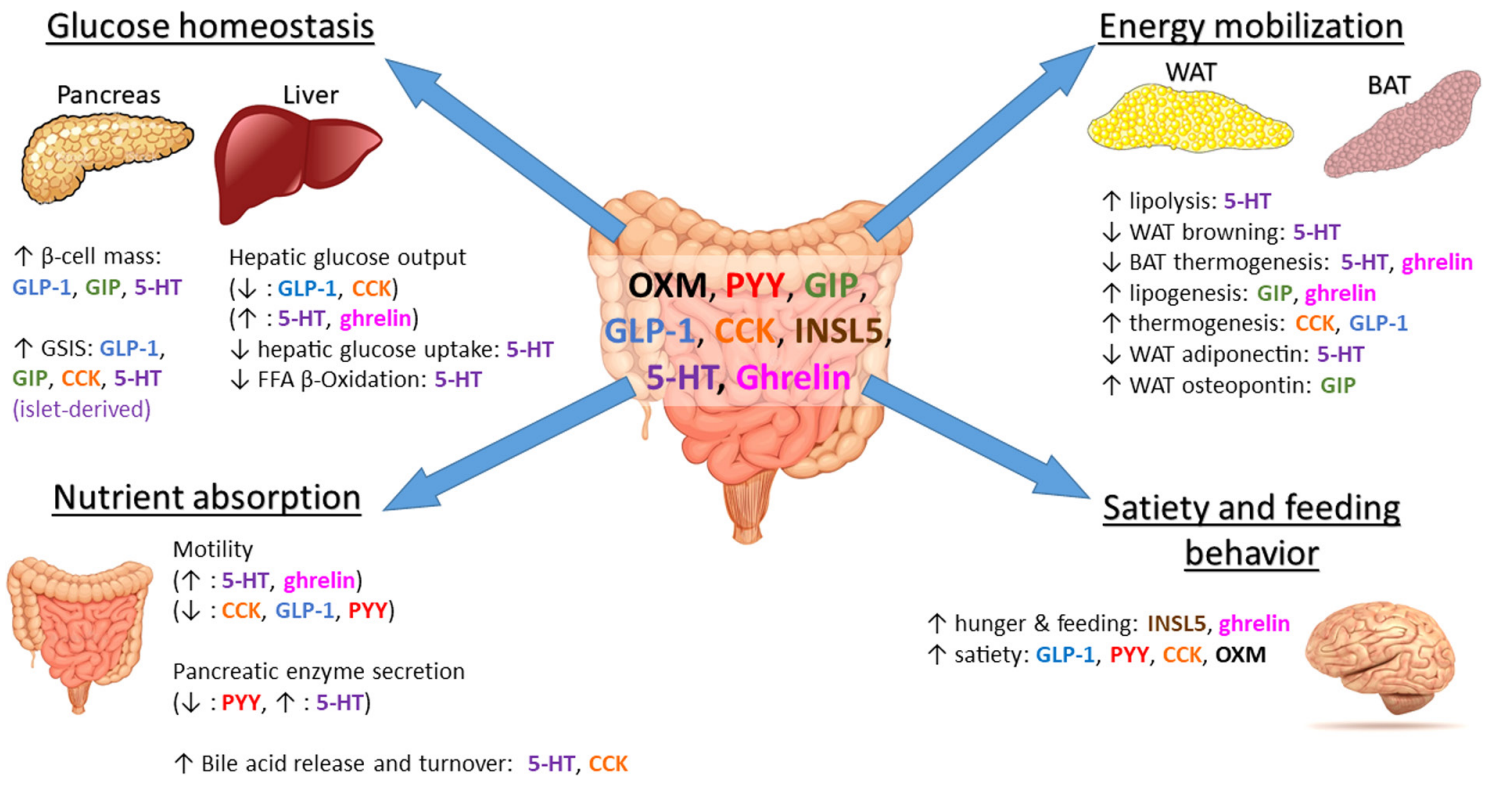

\section{Figure 1}

The role of gut hormones in metabolically important organs. Gut hormones are implicated in the regulation in glucose homeostasis through their differential actions on the liver and endocrine pancreas. They also play important roles in maintaining energy balance by modulating nutrient absorption, mobilization of fat stores from adipose tissue and appetite regulation. 5-HT, serotonin; CCK, cholecystokinin; GIP, glucose-dependent insulinotropic peptide; GLP-1, glucagon-like peptide 1; INSL5, insulin-like peptide 5; PYY, peptide YY; OXM, oxyntomodulin; BAT, brown adipose tissue; WAT, white adipose tissue.

https://joe.bioscientifica.com https://doi.org/10.1530/JOE-19-0399 (c) 2020 The authors Published by Bioscientifica Ltd. Printed in Great Britain

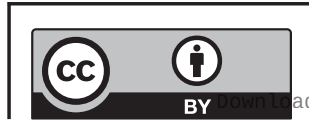

This work is licensed under a Creative Commons Attribution 4.0 International License. ded from Bioscientifica.com at $04 / 26 / 2023$ 10:31:17AM 
K cells release GLP-1 and GIP, respectively, in response to intraluminal glucose and these two peptides then stimulate pancreatic $\beta$ cells in an endocrine manner. While $\beta$ cell GLP-1R have been consistently demonstrated to be essential for maintaining glucose homeostasis (Smith et al. 2014, Grasset et al. 2017), the physiological ligand for $\beta$ cell GLP-1R remains a subject of controversy. Small amount of GLP-1 has been demonstrated to be produced by pancreatic islets (Marchetti et al. 2012) and Chambers et al. reported glucose tolerance in mice was significantly impaired by islet-, but not intestinalspecific ablation of $G c g$ (encodes of proglucagon derived peptides that include glucagon, GLP-1, GLP-2 and oxyntomodulin) (Chambers et al. 2017), supporting the notion that it is islet-derived, in a paracrine manner, rather than gut-derived GLP-1, in an endocrine fashion, that is crucial for gluco-regulation. However, this view has been challenged by several recent findings. Firstly, other groups have reported that only an extremely small amount of GLP-1 is produced by islet under normal physiological conditions (Song et al. 2019). Moreover, $\beta$ cell GLP-1R is activated by glucagon at levels observed within islet microenvironments (Svendsen et al. 2018). As such, one can no longer conclude that islet-derived GLP-1 is essential for glucose homeostasis based on experiments in which a GLP-1R antagonist was used or involved sitespecific Gcg knockdown, since pancreatic glucagon and GLP-1 actions are both blocked in these experiments. The necessity of gut-derived GLP-1 in glucoregulation is further complicated by a recent report showing that when $G c g$ is ablated specifically in the mouse ileum and colon, both oral and intraperitoneal glucose tolerance are significantly impaired, despite a compensatory upregulation of GIP (Song et al. 2019), landing support to the notion that gut-derived GLP-1 does play an essential role in gluco-regluation. Pancreatic $\beta$-cells also synthesise and secrete 5-HT, and this is important for the pregnancyinduced expansion of $\beta$-cell mass that occurs during pregnancy and which is essential to avoid gestational diabetes (Kim et al. 2010).

\section{Liver}

The liver is central in maintaining glucose homeostasis with hepatic glucose output through glycogenolysis and gluconeogenesis being the biggest contributor to plasma glucose levels in the post-absorptive state (Sherwin 1980). During the postprandial period, hepatocytes increase glucose uptake and upregulate glycogen synthesis in response to elevated insulin and reduce glucose output in response to decreased glucagon levels. Dysregulated suppression of hepatic glucose output during the postprandial period is a major driver of postprandial hyperglycaemia in T2D patients (DeFronzo et al. 1989). Several gut-derived hormones contribute to hepatic glucose output through their capacity to augment hepatic gluconeogenesis and glycogenolysis. In addition, hepatic insulin clearance has been recently demonstrated to contribute significantly to insulin action, through controlling insulin availability to peripheral tissues (Bojsen-Moller et al. 2018).

Postprandial release of GLP-1 attenuates hepatic glucose production, independent of its effects on pancreatic islets (Jun et al. 2015), potentially through activation of GLP-1R on vagal afferent nerves innervating the hepatic portal vein (Vahl et al. 2007). CCK suppresses hepatic glucose output in rodents by acting on CCK-A receptors on intestinal vagal afferents projecting to the nuclear solitary tract (NTS), a signalling pathway that is perturbed by diet-induced obesity (Cheung et al. 2009). However, whether such mechanism exist in humans remains a subject of contest. Various in vivo studies indicated that although CCK infusion lowers postprandial plasma glucose levels in humans, this is likely to be mediated by its inhibitory effect on gastric emptying (Liddle et al. 1988, Fried et al. 1991) or potential insulinotropic actions (Ahren et al. 2000), rather than direct effects on the liver. Opposingly, the release of gut-derived 5-HT during fasting increases hepatic gluconeogenesis and glycogenolysis while inhibiting peripheral glucose uptake (Sumara et al. 2012). Perhaps the most well-known of the gut-derived hormones released during fasting is ghrelin, with intraduodenal infusion increasing hepatic glucose production via GSH-R1a receptors on vagal afferents signalling to the NTS (Lin et al. 2019).

\section{Energy balance}

Energy homeostasis is maintained through a delicate balance between calorie intake and expenditure, which ultimately determines bodyweight. Energy intake is determined by feeding drive and efficiency of nutrient absorption while energy expenditure is primarily governed by energetic cost to maintain basic cellular metabolic processes, thermal regulation and voluntary movements such as exercise. In the next section, we review how gut hormones influence energy balance through their effects of these governing factors. 


\section{Satiety and feeding behaviour}

Gut-derived hormones play an integral role in appetite regulation, which in turn governs food intake, one of the major pillars of maintaining energy balance. The anorexigenic gut hormones GLP-1, PYY, CKK and OXM are released postprandially to induce satiety and reduce food intake whilst levels of the orexigenic hormones ghrelin and INSL5 are elevated during fasting to induce hunger and drive feeding behaviour (Sun et al. 2018). Gut hormones released by EECs stimulate vagal afferent nerve fibres by activating receptors located on nearby nerve endings, which project to appetite control nuclei of the brainstem. The anorectic effects of GLP-1 and CCK are significantly attenuated in vagotomised patients (Joyner et al. 1993, Plamboeck et al. 2013) whilst ghrelin receptors on gastric afferent nerve terminals mediate ghrelin-induced feeding (Date et al. 2002). Diet-induced obesity disrupts this neuroendocrine signalling pathway between the gut and the brain, dampening the activity of anorexigenic hormones and causes hyperphagia (de Lartigue 2016).

Gut hormones can also carry out appetite regulatory effects in an endocrine fashion where, via the fenestrated capillaries, circulating hormones reach the arcuate nucleus (ARC) in the hypothalamus (Cone 2005) as well as the NTS and area postrema (AP) in the brainstem (Murphy $\&$ Bloom 2004). Together, these form the key appetite centres in mammals. Within the ARC, the orexigenic AgRP/NPY neurons are activated during fasting and drive acute food seeking and consumption (Aponte et al. 2011). Ghrelin potently activates AgRP neurons while 5-HT, CCK and PYY, hormones that are released postprandially, all suppress AgRP neuron activity (Beutler et al. 2017). Acute food intake rapidly inhibits AgRP neuron firings (Beutler et al. 2017), resulting in the disinhibition of neighbouring anorexigenic proopiomelanocortin (POMC) neurons. Contrasting the rapid but short-lived effects of AgRP neurons, activation of POMC neurons in the ARC reduces food intake in a delayed but more sustained manner (Aponte et al. 2011). The GLP-1R agonist, liraglutide, acts on GLP-1R on ARC POMC neurons to reduce food intake and protect mice from diet-induced obesity (Burmeister et al. 2017). Within the brainstem, neurons of the NTS and adjacent AP are activated by gut-derived satiety signals primarily via the sensory vagus nerve and to a lesser extent by circulating gut-derived hormones. Similar to neurons within the ARC, the NTS and AP produce both NPY and $\mathrm{POMC}$, and have reciprocal connections with the ARC that allows for extensive communication between the brainstem and hypothalamus to regulate feeding behaviour (Wynne et al. 2005). This central appetiteregulating pathway is made even more complex by the ability of sensory inputs arising from food detection to reverse orexigenic signalling in vivo in mice prior to food consumption. Intriguingly, the magnitude of response to food detection is also dictated by the hedonic properties of the food itself, such as palatability and energy density (Chen et al. 2015). Whether this is also driven by gutderived hormones in response to potential olfactory cues is unknown.

\section{Nutrient absorption}

GI motility heavily influences the digestion and absorption of nutrients across the gut lumen, whereby contributing to glucose homeostasis and overall energy intake. A relationship exists between gastrointestinal motility and glycaemic control, as the rate of gastric emptying heavily influence oral glucose absorption and hence, postprandial glucose excursion (Rayner et al. 2001). CCK, ghrelin, PYY, GLP-1 and 5-HT are potent stimulators of the ENS to modulate GI motility. EC cell-derived 5-HT increases the frequency and force of colonic contractions (Keating \& Spencer 2010). Ghrelin stimulates gastric motility and as such accelerates gastric emptying, alleviating the sense of fullness caused by gastric distention (Muller et al. 2015). Conversely, most of the anorexigenic gut hormones inhibit GI motility. CCK inhibits gastric emptying by mediating vasoactive intestinal peptide-induced relaxation of the gastric fundus as part of a vago-vagal reflex pathway (Grider 1994). GLP-1 delays gastric emptying and potently suppresses small intestinal motility (Hellstrom et al. 2008), an effect that is ascribed to some of the glucose-lowering effect of the GLP-1R agonist, liraglutide (Nakatani et al. 2017). Further to this, another GLP-1R agonist, exenatide, has been demonstrated to clinically suppress small intestinal motility and glucose absorption rate in both healthy individuals and those with type 2 diabetes (Thazhath et al. 2016). Similarly, the other L cell hormone PYY inhibits proximal intestinal motility, as part of an 'ileal break' mechanism (Maljaars et al. 2008).

Optimal nutrient absorption is heavily reliant on efficient digestion of ingested foodstuff, a process that is regulated by gut hormones. CCK is the major gut hormone that triggers gallbladder contraction and exocrine pancreatic secretion. The former releases bile acids, amphiphilic molecules that aid the solubilization of luminal lipids, whilst the latter consists of a mixture of digestive enzymes such as lipase, amylase and proteases, critical for the breakdown of macronutrients.

This work is licensed under a Creative Commons Attribution 4.0 International License. 
Secretin released from the proximal small intestine following exposure to prandial gastric acid also stimulates secretion of pancreatic digestive enzymes and biliary bicarbonate secretion, while also reducing gastric emptying and gastric acid secretion (Afroze et al. 2013). EC cell-derived 5-HT is also implicated in the secretion of pancreatic enzymes and bicarbonate from the exocrine pancreas (Li et al. 2000, 2001), the latter being crucial in neutralizing gastric acid that would otherwise denature the enzymes (Keller \& Layer 2005). An inhibitory role of PYY on exocrine pancreatic secretion had been suggested (Tatemoto 1982, Jin et al. 1993), although this could be mediated by pancreatic islet-derived PYY in a paracrine manner (Shi et al. 2015). While GLP-1 does not appear to directly affect gallbladder motility (Smits et al. 2016), there is evidence in support of a modulatory role to antagonize CCK-induced gallbladder contraction (Keller et al. 2012). On the other hand, a recent study showed that GLP-2, another L cell hormone, induces gallbladder relaxation and promotes gallbladder refilling (Yusta et al. 2017).

\section{Energy mobilization}

Adipose tissue exists as two subtypes: white adipose tissue (WAT) and brown adipose tissue (BAT), each serving distinct metabolic functions. The body's surplus energy is primarily stored in WAT as triglycerides and liberated from the adipocyte as free fatty acids and glycerol when required. Excess adiposity secondary to increased fat storage within WAT is a key driver of obesity. On the other hand, BAT is implicated in thermal adaptation through its thermogenic capacity, dissipating energy harvested from the proton gradient across the inner mitochondrial membrane as heat, instead of coupling to ATP production (Bouillaud et al. 1983). Under certain conditions such as cold exposure, WAT has the capacity to undergo 'browning', whereby the expression of key genes controlling thermogenesis, particularly UCP1, are upregulated and cells transform towards those of a thermogenic phenotype resembling that of BAT (Bartelt \& Heeren 2014). Increasing WAT browning and expanding BAT volume have both been intensely investigated for their anti-obesity potential as both approaches favour the removal of the body's excess energy stores by increasing heat production (Bartelt \& Heeren 2014). Moreover, a recent study has suggested that elevated hypothalamic temperature secondary to BAT-mediated thermogenesis induces satiety by activating POMC neurons in the ARC (Li et al. 2018).

Several gut hormones exert their metabolic effects by targeting adipose tissue, differentially influencing the uptake, utilization and storage of lipids. Many of the obesogenic effects of 5-HT is mediated through its action on adipocytes. Whilst 5-HT potently stimulates lipolysis in WAT to release free fatty acids and glycerol, it impairs $\beta$ oxidation in the liver and WAT (Rozenblit-Susan et al. 2016), preventing these tissue from utilizing the newly available free fatty acids. Moreover, 5-HT reduces energy expenditure by preventing WAT browning (Crane et al. 2015). Together with ghrelin, the two hormones downregulate the thermogenic capacity of BAT (Muller et al. 2015), thereby increasing energy conservation. In addition, together with GIP, ghrelin increases the storage of lipids by upregulating lipogenesis (Getty-Kaushik et al. 2006, Theander-Carrillo et al. 2006). On the other hand, gut hormones that increase thermogenic capacity of adipocytes can prevent the development of obesity. In rodents, CCK and GLP-1 are both implicated in dietinduced thermogenesis in BAT, as they activate vagal afferents which in turns results in increased sympathetic output to BAT (Blouet \& Schwartz 2012, Beiroa et al. 2014). The role of GLP-1 in thermogenic capacity in humans is less clear, however, as several clinical trials with acute exposure to the GLP-1R agonists, liraglutide and exenatide, yield no differences in resting energy expenditure, while prolonged exposure to these agonists increased energy expenditure (Maciel et al. 2018). A recent study showed that the intestinal hormone secretin potently induces prandial BAT thermogenesis, independent of sympathetic activity (Li et al. 2018).

In addition to its critical role in energy storage and thermal regulation, adipose tissue is a prominent regulator of peripheral metabolism through the secretion of a range of adipocyte-derived hormones, termed adipokines. Gut hormones have the capacity to alter the release of these adipokines, which poses another secondary mechanism by which they regulate peripheral metabolism via adipose tissue. Specifically, 5-HT attenuates the release of adiponectin from WAT (Uchida-Kitajima et al. 2008), an insulin-sensitizing, anti-lipogenic and anti-atherogenic adipokine (Stern et al. 2016). GIP upregulates the expression and stimulates the secretion of osteopontin, a pro-inflammatory adipokine derived from WAT that is implicated in the development of obesity-induced insulin resistance (Kiefer et al. 2010).

\section{Mechanisms controlling gut hormone secretion}

Enteroendocrine cells are dispersed throughout the gut epithelium as individual cells. This makes it inherently

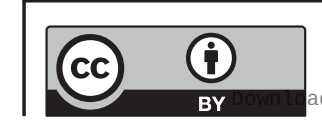

This work is licensed under a Creative Commons Attribution 4.0 International License. 
difficult to isolate and study pure EE cells in culture and, as such, our knowledge on the mechanisms controlling gut hormone secretion has been predominantly derived from cell lines, or ex vivo and in vivo animal models. Recent advances in EE cell purification (Reimann et al. 2008, Martin et al. 2017a, Lund et al. 2018), particularly the availability of transgenic mouse lines in which specific EE cell populations can be fluorescently labelled and sorted (Reimann et al. 2008), have provided valuable insights into our understanding of the molecular mechanisms controlling gut hormone secretion. Functional transcriptomic and proteomic analysis of purified EE cells has revealed that these cells are sensors for an array of luminal nutrients and microbial metabolites (Fig. 2).

\section{Nutrient sensing}

\section{Carbohydrate}

Most EE cell types have the capacity to sense luminal carbohydrates. During a standard oral glucose tolerance test, ghrelin secretion is significantly suppressed (Muller et al. 2015), whilst 5-HT, CCK, GIP and GLP-1 are increased (Gribble \& Reimann 2016). Glucose-induced GLP-1 secretion is primarily driven by glucose-dependent $\mathrm{Na}^{+}$uptake via SGLT-1 and intracellular glucose metabolism, which leads to closure of $\mathrm{K}_{\mathrm{ATP}}$ channels and further depolarisation and exocytosis (Reimann et al. 2008, Gorboulev et al. 2012, Kuhre et al. 2014a, Sun et al. 2017). Additional mechanisms independent of glucose metabolism may also play a role, however, as consumption of the non-metabolised SGLT-1 substrate, 3-O-methylglucose, also increases plasma GLP-1 in humans (Wu et al. 2012). What these mechanisms are, precisely, remains unknown. Other EE cells, such as GIP-secreting K cells may also sense glucose via similar metabolism-dependent mechanisms (Parker et al. 2009). On the other hand, the underlying mechanisms driving glucose-induced 5-HT release remains to be determined, although 5-HT secreting enterochromaffin (EC) cells are clearly glucose-sensitive in vitro (Martin et al. 2017b, Lumsden et al. 2019) and in vivo (Young et al. 2018), and express a myriad of glucose sensors, such as SGLT1, GLUT2 and the sweet taste receptor T1R2/T1R3 (Martin et al. 2017a). Although ghrelin-secreting X/A cells demonstrate sensitivity to glucose in vitro (Sakata et al. 2012), they do not appear to directly sense luminal or vascular glucose in vivo (Schaller et al. 2003, Williams et al. 2003).

Fructose occurs naturally in fruit but the primary source of fructose in the modern diet is in the form of sucrose, a disaccharide, which is degraded by sucrase into glucose and fructose. Fructose transport and absorption is mediated by GLUT5, which is expressed in EC cells (Martin et al. 2017a), L cells (Reimann et al. 2008) and $\mathrm{K}$ cells (Parker et al. 2009). Fructose triggers the release of 5-HT (Martin et al. 2017b), GLP-1, CCK and PYY, but despite K cells expressing GLUT5, luminal fructose does not elicit in vivo GIP release in mice, rats or humans (Kuhre et al. 2014b). Further interrogation using a GLP1-secreting cell line suggests that fructose-induced GLP-1 secretion is mediated by intracellular metabolism and subsequent closure of $\mathrm{K}_{\text {АTP }}$ channels (Kuhre et al. 2014b), although this remains to be confirmed in primary L cells. EECs also express sweet taste receptors (STRs), which comprise a heterodimer of the GPCRs T1R2 and T1R3 (Steinert et al. 2011, Kreuch et al. 2018). Genetic ablation of T1r3 or the STR subunit, a-gustducin, significantly

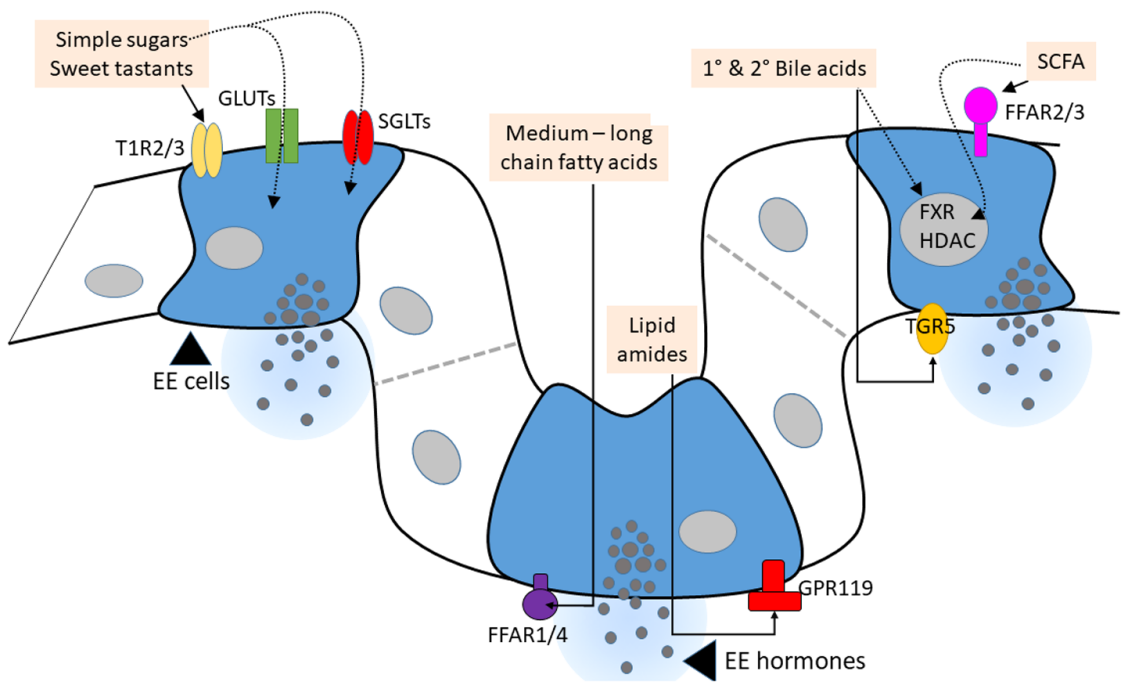

Figure 2

Activation of enteroendocrine (EE) cells. Carbohydrates in the gut lumen such as simple sugars are sensed by sodium-glucose transporters (SGLTs), glucose transporters (GLUTs) and sweet taste receptors (T1R2/3). Lipids are sensed basolaterally, with medium- and long-chain fatty acids activating free fatty acid receptors (FFARs) 1 and 4 and lipid amides activating G-protein receptor 119 (GPR119). EE cell secretion is also differentially regulated by individual bile acids, which signal through the GPCR, Takeda G-protein receptor 5 (TGR5) on the basolateral membrane and through the nuclear receptor, Farnesoid X receptor (FXR). Short-chain fatty acids (SCFAs) derived from bacterial fermentation of indigestible polysaccharides, also influence EE cell secretion through activating FFARs 2 and 3 and inhibiting histone deacetylases (HDACS). https://joe.bioscientifica.com https://doi.org/10.1530/JOE-19-0399 (c) 2020 The authors Published by Bioscientifica Ltd. Printed in Great Britain

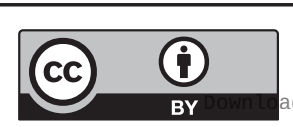

This work is licensed under a Creative Commons Attribution 4.0 International License. ed from Bioscientifica.com at 04/26/2023 10:31:17AM 
attenuated GLP-1 secretion upon an OGTT in mice (Jang et al. 2007, Kokrashvili et al. 2009). Although sugars are agonists for STRs, whether or not they are directly implicated in glucose-induced incretin secretion is still a subject of controversy (Gerspach et al. 2011, Steinert et al. 2011, Saltiel et al. 2017).

\section{Proteins}

Protein ingestion is a potent stimulant for the secretion of a range of gut hormones. Ingested proteins are broken down into oligopeptides and individual amino acids by proteases in the stomach. Peptides are translocated across the gut wall by the proton-coupled oligopeptide transporter PEPT1 (also known as SLC15A1), which is expressed by EECs secreting CCK (Liou et al. 2011a) and GLP-1 (Diakogiannaki et al. 2013). PEPT1 activity is electrogenically coupled to protons and its activation contributes to the lowering of membrane potential (Fei et al. 1994). PEPT1 activity is required for protein hydrolysate-induced GLP-1 secretion from murine small intestinal enteroids (Zietek et al. 2015) and mixed epithelial cell culture (Diakogiannaki et al. 2013), which underpins the reduction of endogenous glucose production by casein hydrolysates in rats (Dranse et al. 2018). However, the mechanisms underlying protein hydrolysate-induced I cell secretion remains to be elucidated as PEPT1 is not necessary for triggering CCK release in vitro (Liou et al. 2011a). Individual amino acids can also trigger the release of a range of gut hormones by activating different GPCRs. CaSR was first described as a calcium sensor and was later shown to be an amino acid sensor, preferentially activated by aromatic amino acids such as tryptophan and phenylalanine, but not branched chain amino acids (Conigrave et al. 2000). CCK (Liou et al. 2011c), GIP (Mace et al. 2012) and GLP-1 cells (Diakogiannaki et al. 2013) all express CaSR and tryptophan-induced gut hormone secretion is reliant on CaSR activity (Mace et al. 2012). GPR142 is implicated in tryptophan, but not protein-induced GIP and GLP-1 release (Rudenko et al. 2019). GIP-secreting K cells express high levels of the basic amino acid sensor GPRC6a (Sommer \& Mostoslavsky 2014), which is activated by arginine and lysine but is insensitive to aromatic acids (Wellendorph et al. 2005). Intraduodenal infusion of the branched chain amino acid (BCAA) leucine stimulates the release of CCK but not other gut hormones (Steinert et al. 2015), while valine, another BCAA, does not stimulate CCK release (Elovaris et al. 2019). Emerging evidence suggests leucinestimulated CCK secretion is mediated through the umami taste receptor T1R1/T1R3 (Tian et al. 2019).
Dietary protein can also regulate gut hormone biosynthesis, predominantly through the activation of mTOR, the highly conserved master regulator of cellular anabolic processes. Mice with EEC-specific deletion of TSC1, an endogenous mTOR inhibitor, had higher circulating GLP-1 levels and increased ileal proglucagon mRNA and protein levels. Elevated baseline GLP-1 is also seen with a 6-day treatment with leucine, which is associated with increased ileal proglucagon protein content. Conversely, same treatment duration with rapamycin, which potently suppresses mTOR activity, significantly decreases circulating GLP-1 levels and reversed the effects of leucine treatment (Xu et al. 2015). On the other hand, the biosynthesis of the orexigenic hormone ghrelin is suppressed by increased amino acid availability through increased mTOR activity in X/A cells, while rapamycin significantly increases circulating ghrelin levels (Xu et al. 2009, 2012). Moreover, mTOR activation also results in the downregulation of the expression of GOAT, the rate-limiting enzyme of ghrelin acylation (Muller et al. 2015), thereby reducing the availability of active ghrelin (Li et al. 2019, Mao et al. 2019). As such, reduced protein availability could drive hunger by increasing ghrelin levels.

\section{Lipids}

Dietary lipids are typically ingested in the form of triglycerides, which are broken down by pancreatic lipase into long-chain fatty acids (LCFAs) and monoacylglycerols (MAGs). These are either passively absorbed or undergo facilitated transport into enterocytes and resynthesised into triglycerides, packaged into chylomicrons and released into the lymphatic system (Iqbal \& Hussain 2009). Free fatty acids signal via G-protein-coupled free fatty acid receptors (FFAR), several of which have been identified in EE cell populations and convey the ability to sense luminal short-, medium- and long-chain fatty acids. Ingestion of lipids stimulates the in vivo release of many gut hormones, including CCK, GLP-1 and GIP (Isaacs et al. 1987, Ekberg et al. 2016, Mandoe et al. 2018). Expression of the lipid amide receptor, GPR119, which is activated by monoacylglycerols, has been demonstrated in EC cells (Martin et al. 2017a), L cells (Chu et al. 2008), I cells (Sykaras et al. 2012) and K cells (Parker et al. 2012) and enhances the secretion of GLP-1 and GIP, but not CCK or PYY, in humans in vivo (Hansen et al. 2011). Moreover, agonists for FFAR1 and GRP119 stimulate secretion of GLP-1 (Lan et al. 2012, Moss et al. 2016) (Christensen et al . 2015) in various in vitro models, while lipid-induced GIP, CCK and GLP-1 release is substantially compromised

This work is licensed under a Creative Commons Attribution 4.0 International License. 
in Ffar1 and Ffar4-deficient mice (Liou et al. 2011b, Iwasaki et al. 2015, Sankoda et al. 2017). Intraduodenal lipid infusion increases the expression of FFAR1 and is positively correlated with GIP secretion, suggesting longchain fatty acids may drive an increase in GIP secretion (Cvijanovic et al. 2017).

It was once thought that localisation of receptors for lipid sensing were exclusive to the apical membrane of EECs, which would allow them to directly sense luminal lipids. However, emerging evidence appears to refute this model. Vascular, but not luminal administration of the long-chain fatty acid linoleic acid and FFAR1 agoniststimulated GLP-1 secretion in an ex vivo rat small intestine perfusion model (Christensen et al. 2015), thereby suggesting that FFAR1 resides in the basolateral membrane of GLP-1-secreting L cells. Moreover, the formation of chylomicrons appears pivotal in lipid-induced CCK (Glatzle et al. 2003), GLP-1 and GIP secretion (Lu et al. 2012, Psichas et al. 2017). While the immunoglobulinlike domain-containing receptor 1 has been identified as a CCK-specific chylomicron sensor (Chandra et al. 2013), the mechanisms controlling chylomicron-induced GLP-1 and GIP secretion remain to be elucidated, as it is not affected by the blockade of lipoprotein lipase or the inhibition of GPR119 or FFAR1 signalling (Psichas et al. 2017).

\section{Bile acid sensing}

Bile acids are amphiphilic molecules synthesized by hepatocytes from cholesterol and stored in the gallbladder. Upon exposure to lipids in the GI lumen, I cells release CCK that then triggers gallbladder contraction to release bile into the duodenum to aid the solubilization of lipids, facilitating their absorption (Lefebvre et al. 2009). The majority of bile acids are actively reabsorbed in the terminal ileum by apical sodium bile acid transporter and approximately 5\% enters the colon, where their hydrophobicity is enhanced by microbial metabolism, thus enabling some of the bile acids to be passively absorbed while the remainder are excreted (Lefebvre et al. 2009). In addition to their role as GI detergents, bile acids are signalling molecules that have important implications in peripheral metabolism. The acute stimulatory effect of bile acids on EECs is mediated by the Takeda G-protein-coupled receptor 5 (TGR5), which results in elevated intracellular cAMP levels and PKA activation (Goldspink et al. 2018). TGR5 expression has been confirmed in various enteroendocrine cell types, including L cells (Kuhre et al. 2018) and colonic EC cells (Alemi et al. 2013). Acute bile acid exposure stimulates the release of GLP-1 and PYY from L-cells in the small intestine and colon (Adrian et al. 2012, Wu et al. 2013a,b, Brighton et al. 2015, Hansen et al. 2016, Kuhre et al. 2018, Christiansen et al. 2019) and chronic TGR5 activation increases proglucagon biosynthesis (Harach et al. 2012), which may underpin the increased basal GLP-1 levels observed in TGR5 agonist-treated mice (Thomas et al. 2009). Bile acids have an inhibitory effect on CCK release (Koop et al. 1988, Koide et al. 1993, Marina et al. 2012), but it remains to be determined if this is TGR5 mediated. Bile acid sequestrants, which are anionic exchange resins that inhibits bile acid reabsorption in the terminal ileum, markedly increases GLP-1 levels in rodents in a TGR5dependent manner (Harach et al. 2012). However, these effects have not been reliably translated to humans (Beysen et al. 2012, Smushkin et al. 2013, Hansen et al. 2016, Bronden et al. 2018).

Bile acid signal transduction in EECs is also carried out via the nuclear Farnesoid X receptor (FXR) (Lefebvre et al. 2009), which influences gene transcription pathways and the biosynthesis of gut hormones, rather than activating hormone release (Kuhre et al. 2018). FXR activation inhibits proglucagon biosynthesis (Jiang et al. 2015), thereby reducing the fasting plasma GLP-1 levels (Albaugh et al. 2019, Pierre et al. 2019). Conversely, intestinal-specific FXR inhibition results in increased intestinal proglucagon mRNA and circulating GLP-1 levels in mice (Trabelsi et al. 2015) but does not change circulating GIP and ghrelin levels (Pierre et al. 2019). The effects of FXR activation on other gut hormones remain unclear, as is the mechanisms by which intestinal FXR regulate peripheral metabolism.

\section{Microbial sensing}

The GI tract is host to an abundance of gut microbes, or microbiota, and together with the genetic traits (collectively referred to as the gut microbiome), contribute profoundly to host metabolic processes. The importance of the gut microbiome in host metabolism has been elegantly demonstrated through the use of faecal microbiota transfer from lean and obese humans and obese mice into germ-free (GF) mice lacking a native gut microbiome, which conveys the metabolic phenotype from the donor to the host (Turnbaugh et al. 2006, 2009, Backhed et al. 2007). In addition, a core obese microbiome has been identified in humans, which contributes to obesity progression and the dysregulation of metabolism through an increase in energy harvest (Turnbaugh et al. 2006, 2009). It has now been established that there is bidirectional signalling between EE cells and the resident

This work is licensed under a Creative Commons Attribution 4.0 International License. 
gut microbiota, which is unsurprising, considering they are constitutively in direct contact with the other (Martin et al. 2019).

The importance of the signalling from the microbiota to EECs is evident in reports that GF mice or broadspectrum antibiotic-treated mice have markedly elevated circulating GLP-1 (Grasset et al. 2017) but reduced 5-HT (Yano et al. 2015). In addition to acute hormone release, the microbiota also has profound impact on gut hormone biosynthesis at the cellular level and the composition of the EE cell population. Reduced CCK and proglucagon protein expression is observed in dissociated cells from the proximal small intestine of GF mice, which was not due to reduced numbers of EE cells (Duca et al. 2012). Conversely, the presence of a gut microbiome acts in a chronic manner to increase the biosynthesis of 5-HT (Reigstad et al. 2015), contributed to by an increase in the density of 5-HT-containing cells compared to GF mice (Yano et al. 2015). Gut microbiota signal to EE cells through several mechanisms, including the release of microbial structural components such as lipopolysaccharides and metabolites such as short-chain fatty acids (SCFAs) and secondary bile acids (Martin et al. 2019).

Most mammals do not possess the enzymes to metabolise indigestible carbohydrates such as cellulose. The ability for the gut microbiota to utilize these insoluble fibre and harvest energy forms the foundation of the symbiotic relationship between host and its resident gut microbiota. Resulting metabolites can then serve as signalling molecules that regulate host metabolism or as energy substrates. Short-chain fatty acids (SCFAs) are the primary breakdown products of this process and they signal via the G-protein-coupled free fatty acid receptors (FFAR) 2 and 3 (Offermanns 2014) or by modulating nuclear histone deacetylase (HDAC) activity (Waldecker et al. 2008, Fellows et al. 2018, Larraufie et al. 2018). SCFA signalling through FFAR2 and FFAR3 in EE cells occurs via different secondary pathways, with each receptor having differing affinities for the dominant SCFAs: acetate, propionate and butyrate (Offermanns 2014). The expression of FFAR2 and FFAR3 has been identified in 5-HT-producing EC cells (Martin et al. 2017a) and GLP-1/PYY-producing L cells (Nohr et al. 2013). SCFAs are potent GLP-1 secretagogues (Tolhurst et al. 2012), stimulating $\mathrm{L}$ cells secretion in a region-specific manner. SCFA signalling in the small intestine occurs primarily through FFAR3, whilst FFAR2 mediates GLP-1 release from colonic L cells (Greiner \& Backhed 2011). Chronic SCFA treatment increases the density of PYY-containing cells (Brooks et al. 2017), as well as PYY biosynthesis in a dose- and time-dependent manner in both EE cell lines and primary human colonic cells (Larraufie et al. 2018). On the other hand, acute exposure of primary EC cells from mice to SCFA in culture does not increase 5-HT release (Martin et al. 2017b).

In addition to indigestible carbohydrates, the gut microbiota also metabolise a range of substrates present in the intestinal lumen. Aforementioned, the intestinal flora drives the deconjugation and dihydroxylation of bile acids that escapes active reabsorption in the terminal ileum, forming secondary bile acids, which are more hydrophobic and can thus enter the enterohepatic circulation via passive diffusion (Lefebvre et al. 2009). As individual bile acids having different signalling profiles at TGR5 and FXR (Kuhre et al. 2018) and as such, the microbiota can influence gut hormone secretion by altering the composition of the bile acid pool. Microbial metabolites derived from amino acid metabolism have also been shown to modulate gut hormone secretion. While the majority of dietary proteins and amino acids are absorbed in the small intestine, small amounts of unabsorbed amino acids could go through the ileocaecal valve to enter the colon (Chung et al. 1979), and thus, serve as a nitrogen source for the colonic microbiota. Indole and hydrogen sulphide are metabolites produced by microbial metabolism of tryptophan and cysteine, respectively, and have both been shown to acutely stimulate GLP-1 secretion in GLUTag cells, a L cell-like GLP-1-secreting cell line (Chimerel et al. 2014, Pichette et al. 2017). Isovalerate, a volatile fatty acid derived from valine fermentation (Zarling \& Ruchim 1987), has been identified as a potent EC cell secretagogue (Bellono et al. 2017).

The presence of the microbiota in the gastrointestinal lumen represents a rich source of microbial-associated molecular patterns (MAMPs), which are evolutionarily conserved microbial structures that are recognized by host immune cells through a range of pattern recognition receptors (PRRs). It has been speculated that EECs possess the same machinery (Bogunovic et al. 2007). GLP-1 secretion is markedly elevated upon LPS exposure in vivo in both mice (Kahles et al. 2014) and humans. However, emerging evidence suggests the stimulatory effect of LPS on L cells may be indirect. LPS only increased GLP-1 levels when administered systemically or in animal models of impaired intestinal barrier function (Kahles et al. 2014, Lebrun et al. 2017), implying any potential sensing machinery resides basolaterally. Importantly, LPS-induced GLP-1 increase is abolished in mice deficient in receptor for the proinflammatory cytokine IL-6 (Kahles et al. 2014), a known L cell secretagogue (Ellingsgaard et al. 2011). 
Together, these observations suggest that MAMP-induced gut hormone release is likely to be a reaction associated with systemic exposure, rather than to microbial structural components derived from the gut microbiota locally.

\section{Summary}

There is a growing appreciation for the role of the gastrointestinal tract in maintaining energy and glucose homeostasis and gut-derived hormones contribute significantly to metabolic control. Enteroendocrine cells are key players in driving the metabolic functions of the gut as they release a host of different hormones in response to various luminal and vascular stimuli to elicit adequate metabolic responses, either in an endocrine manner or via the gut-brain axis through activation of extrinsic nerves. As such, enteroendocrine cells and gut hormones are in themselves, important drug targets for anti-obesity and anti-diabetes therapies and a better understanding of gut hormone physiology will greatly facilitate this process.

\section{Declaration of interest}

The authors declare that there is no conflict of interest that could be perceived as prejudicing the impartiality of this review.

\section{Funding}

This work did not receive any specific grant from any funding agency in the public, commercial or not-for-profit sector.

\section{References}

Adrian TE, Gariballa S, Parekh KA, Thomas SA, Saadi H, Al Kaabi J, Nagelkerke N, Gedulin B \& Young AA 2012 Rectal taurocholate increases L cell and insulin secretion, and decreases blood glucose and food intake in obese type 2 diabetic volunteers. Diabetologia 55 2343-2347. (https://doi.org/10.1007/s00125-012-2593-2)

Afroze S, Meng F, Jensen K, McDaniel K, Rahal K, Onori P, Gaudio E, Alpini G \& Glaser SS 2013 The physiological roles of secretin and its receptor. Annals of Translational Medicine 1 29. (https://doi. org/10.3978/j.issn.2305-5839.2012.12.01)

Ahlman H \& Nilsson 2001 The gut as the largest endocrine organ in the body. Annals of Oncology 12 (Supplement 2) S63-S68. (https://doi. org/10.1093/annonc/12.suppl_2.s63)

Ahren B, Holst JJ \& Efendic S 2000 Antidiabetogenic action of cholecystokinin-8 in type 2 diabetes. Journal of Clinical Endocrinology and Metabolism 85 1043-1048. (https://doi.org/10.1210/ jcem.85.3.6431)

Albaugh VL, Banan B, Antoun J, Xiong Y, Guo Y, Ping J, Alikhan M, Clements BA, Abumrad NN \& Flynn CR 2019 Role of bile acids and GLP-1 in mediating the metabolic improvements of bariatric surgery. Gastroenterology 156 1041.e4-1051.e4. (https://doi.org/10.1053/j. gastro.2018.11.017)

Alemi F, Poole DP, Chiu J, Schoonjans K, Cattaruzza F, Grider JR, Bunnett NW \& Corvera CU 2013 The receptor TGR5 mediates the prokinetic actions of intestinal bile acids and is required for norma defecation in mice. Gastroenterology 144 145-154. (https://doi. $\operatorname{org} / 10.1053 /$ j.gastro.2012.09.055)

Aponte Y, Atasoy D \& Sternson SM 2011 AGRP neurons are sufficient to orchestrate feeding behavior rapidly and without training. Nature Neuroscience 14 351-355. (https://doi.org/10.1038/nn.2739)

Backhed F, Manchester JK, Semenkovich CF \& Gordon JI 2007 Mechanisms underlying the resistance to diet-induced obesity in germ-free mice. PNAS 104 979-984. (https://doi.org/10.1073/ pnas.0605374104)

Bartelt A \& Heeren J 2014 Adipose tissue browning and metabolic health. Nature Reviews: Endocrinology 10 24-36. (https://doi.org/10.1038/ nrendo.2013.204)

Beiroa D, Imbernon M, Gallego R, Senra A, Herranz D, Villarroya F Serrano M, Ferno J, Salvador J, Escalada J, et al. 2014 GLP-1 agonism stimulates brown adipose tissue thermogenesis and browning through hypothalamic AMPK. Diabetes 63 3346-3358. (https://doi. org/10.2337/db14-0302)

Bellono NW, Bayrer JR, Leitch DB, Castro J, Zhang C, O'Donnell TA, Brierley SM, Ingraham HA \& Julius D 2017 Enterochromaffin cells are gut chemosensors that couple to sensory neural pathways. Cell $\mathbf{1 7 0}$ 185.e16-198.e16. (https://doi.org/10.1016/j.cell.2017.05.034)

Beutler LR, Chen Y, Ahn JS, Lin YC, Essner RA \& Knight ZA 2017 Dynamics of gut-brain communication underlying hunger. Neuron 96 461.e5-475.e5. (https://doi.org/10.1016/j.neuron.2017.09.043)

Beysen C, Murphy EJ, Deines K, Chan M, Tsang E, Glass A, Turner SM, Protasio J, Riiff T \& Hellerstein MK 2012 Effect of bile acid sequestrants on glucose metabolism, hepatic de novo lipogenesis, and cholesterol and bile acid kinetics in type 2 diabetes: a randomised controlled study. Diabetologia 55 432-442. (https://doi.org/10.1007/ s00125-011-2382-3)

Blouet C \& Schwartz GJ 2012 Duodenal lipid sensing activates vagal afferents to regulate non-shivering brown fat thermogenesis in rats. PLOS ONE 7 e51898. (https://doi.org/10.1371/journal.pone.0051898) Bogunovic M, Dave SH, Tilstra JS, Chang DT, Harpaz N, Xiong H, Mayer LF \& Plevy SE 2007 Enteroendocrine cells express functional toll-like receptors. American Journal of Physiology: Gastrointestinal and Liver Physiology 292 G1770-G1783. (https://doi.org/10.1152/ ajpgi.00249.2006)

Bojsen-Moller KN, Lundsgaard AM, Madsbad S, Kiens B \& Holst JJ 2018 Hepatic insulin clearance in regulation of systemic insulin concentrations-role of carbohydrate and energy availability. Diabetes 67 2129-2136. (https://doi.org/10.2337/db18-0539)

Bouillaud F, Combes-George M \& Ricquier D 1983 Mitochondria of adult human brown adipose tissue contain a 32,000-Mr uncoupling protein. Bioscience Reports 3 775-780. (https://doi.org/10.1007/ bf01120989)

Brighton CA, Rievaj J, Kuhre RE, Glass LL, Schoonjans K, Holst JJ, Gribble FM \& Reimann F 2015 Bile acids trigger GLP-1 release predominantly by accessing basolaterally located $\mathrm{G}$ protein-coupled bile acid receptors. Endocrinology 156 3961-3970. (https://doi. org/10.1210/en.2015-1321)

Bronden A, Alber A, Rohde U, Gasbjerg LS, Rehfeld JF, Holst JJ, Vilsboll T \& Knop FK 2018 The bile acid-sequestering resin sevelamer eliminates the acute GLP-1 stimulatory effect of endogenously released bile acids in patients with type 2 diabetes. Diabetes, Obesity and Metabolism 20 362-369. (https://doi.org/10.1111/dom.13080)

Brooks L, Viardot A, Tsakmaki A, Stolarczyk E, Howard JK, Cani PD, Everard A, Sleeth ML, Psichas A, Anastasovskaj J, et al. 2017 Fermentable carbohydrate stimulates FFAR2-dependent colonic PYY cell expansion to increase satiety. Molecular Metabolism 6 48-60. (https://doi.org/10.1016/j.molmet.2016.10.011)

Burmeister MA, Ayala JE, Smouse H, Landivar-Rocha A, Brown JD, Drucker DJ, Stoffers DA, Sandoval DA, Seeley RJ \& Ayala JE 2017 The hypothalamic glucagon-like peptide 1 receptor is sufficient but not necessary for the regulation of energy balance and glucose homeostasis in mice. Diabetes 66 372-384. (https://doi.org/10.2337/ db16-1102)

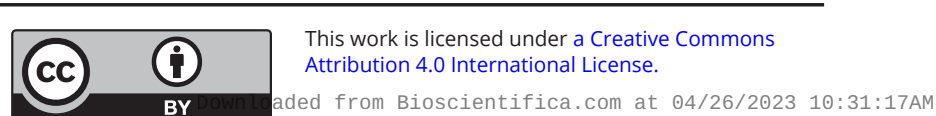


Chambers AP, Sorrell JE, Haller A, Roelofs K, Hutch CR, Kim KS, Gutierrez-Aguilar R, Li B, Drucker DJ, D’Alessio DA, et al. 2017 The role of pancreatic preproglucagon in glucose homeostasis in mice. Cell Metabolism 25 927.e3-934.e3. (https://doi.org/10.1016/j. cmet.2017.02.008)

Chandra R, Wang Y, Shahid RA, Vigna SR, Freedman NJ \& Liddle RA 2013 Immunoglobulin-like domain containing receptor 1 mediates fatstimulated cholecystokinin secretion. Journal of Clinical Investigation 123 3343-3352. (https://doi.org/10.1172/JCI68587)

Chen Y, Lin YC, Kuo TW \& Knight ZA 2015 Sensory detection of food rapidly modulates arcuate feeding circuits. Cell 160 829-841. (https:// doi.org/10.1016/j.cell.2015.01.033)

Cheung GW, Kokorovic A, Lam CK, Chari M \& Lam TK 2009 Intestinal cholecystokinin controls glucose production through a neuronal network. Cell Metabolism 10 99-109. (https://doi.org/10.1016/j. cmet.2009.07.005)

Chimerel C, Emery E, Summers DK, Keyser U, Gribble FM \& Reimann F 2014 Bacterial metabolite indole modulates incretin secretion from intestinal enteroendocrine L cells. Cell Reports 9 1202-1208. (https:// doi.org/10.1016/j.celrep.2014.10.032)

Christensen LW, Kuhre RE, Janus C, Svendsen B \& Holst JJ 2015 Vascular, but not luminal, activation of FFAR1 (GPR40) stimulates GLP-1 secretion from isolated perfused rat small intestine. Physiological Reports 3 e12551. (https://doi.org/10.14814/phy2.12551)

Christiansen CB, Trammell SAJ, Wewer Albrechtsen NJ, Schoonjans K, Albrechtsen R, Gillum MP, Kuhre RE \& Holst JJ 2019 Bile acids drive colonic secretion of glucagon-like-peptide 1 and peptide-YY in rodents. American Journal of Physiology: Gastrointestinal and Liver Physiology 316 G574-G584. (https://doi.org/10.1152/ ajpgi.00010.2019)

Chu ZL, Carroll C, Alfonso J, Gutierrez V, He H, Lucman A, Pedraza M, Mondala H, Gao H, Bagnol D, et al. 2008 A role for intestinal endocrine cell-expressed $\mathrm{G}$ protein-coupled receptor 119 in glycemic control by enhancing glucagon-like peptide- 1 and glucose-dependent insulinotropic peptide release. Endocrinology 149 2038-2047. (https:// doi.org/10.1210/en.2007-0966)

Chung YC, Kim YS, Shadchehr A, Garrido A, Macgregor IL \& Sleisenger MH 1979 Protein digestion and absorption in human small intestine. Gastroenterology 76 1415-1421. (https://doi. org/10.1016/0016-5085(79)90410-4)

Cone RD 2005 Anatomy and regulation of the central melanocortin system. Nature Neuroscience 8 571-578. (https://doi.org/10.1038/ nn1455)

Conigrave AD, Quinn SJ \& Brown EM 2000 L-amino acid sensing by the extracellular Ca2+-sensing receptor. PNAS 97 4814-4819. (https://doi org/10.1073/pnas.97.9.4814)

Crane JD, Palanivel R, Mottillo EP, Bujak AL, Wang H, Ford RJ, Collins A, Blumer RM, Fullerton MD, Yabut JM, et al. 2015 Inhibiting peripheral serotonin synthesis reduces obesity and metabolic dysfunction by promoting brown adipose tissue thermogenesis. Nature Medicine $\mathbf{2 1}$ 166-172. (https://doi.org/10.1038/nm.3766)

Cvijanovic N, Isaacs NJ, Rayner CK, Feinle-Bisset C, Young RL \& Little TJ 2017 Lipid stimulation of fatty acid sensors in the human duodenum: relationship with gastrointestinal hormones, BMI and diet. International Journal of Obesity 41 233-239. (https://doi.org/10.1038/ ijo.2016.199)

Date Y, Murakami N, Toshinai K, Matsukura S, Niijima A, Matsuo H, Kangawa K \& Nakazato M 2002 The role of the gastric afferent vagal nerve in ghrelin-induced feeding and growth hormone secretion in rats. Gastroenterology 123 1120-1128. (https://doi.org/10.1053/ gast.2002.35954)

de Lartigue G 2016 Role of the vagus nerve in the development and treatment of diet-induced obesity. Journal of Physiology 5945791 5815. (https://doi.org/10.1113/JP271538)

DeFronzo RA, Ferrannini E \& Simonson DC 1989 Fasting hyperglycemia in non-insulin-dependent diabetes mellitus: contributions of

https://joe.bioscientifica.com https://doi.org/10.1530/JOE-19-0399 (c) 2020 The authors Published by Bioscientifica Ltd. Printed in Great Britain excessive hepatic glucose production and impaired tissue glucose uptake. Metabolism: Clinical and Experimental 38 387-395. (https://doi. org/10.1016/0026-0495(89)90129-7)

Diakogiannaki E, Pais R, Tolhurst G, Parker HE, Horscroft J, Rauscher B, Zietek T, Daniel H, Gribble FM \& Reimann F 2013 Oligopeptides stimulate glucagon-like peptide- 1 secretion in mice through protoncoupled uptake and the calcium-sensing receptor. Diabetologia 56 2688-2696. (https://doi.org/10.1007/s00125-013-3037-3)

Dranse HJ, Waise TMZ, Hamr SC, Bauer PV, Abraham MA, Rasmussen BA \& Lam TKT 2018 Physiological and therapeutic regulation of glucose homeostasis by upper small intestinal PepT1-mediated protein sensing. Nature Communications 9 1118. (https://doi.org/10.1038/ s41467-018-03490-8)

Duca FA, Swartz TD, Sakar Y \& Covasa M 2012 Increased oral detection, but decreased intestinal signaling for fats in mice lacking gut microbiota. PLoS ONE 7 e39748. (https://doi.org/10.1371/journal. pone.0039748)

Ekberg JH, Hauge M, Kristensen LV, Madsen AN, Engelstoft MS, Husted AS, Sichlau R, Egerod KL, Timshel P, Kowalski TJ, et al. 2016 GPR119, a major enteroendocrine sensor of dietary triglyceride metabolites coacting in synergy with FFA1 (GPR40). Endocrinology 157 4561-4569. (https://doi.org/10.1210/en.2016-1334)

Ellingsgaard H, Hauselmann I, Schuler B, Habib AM, Baggio LL, Meier DT, Eppler E, Bouzakri K, Wueest S, Muller YD, et al. 2011 Interleukin-6 enhances insulin secretion by increasing glucagon-like peptide-1 secretion from L cells and alpha cells. Nature Medicine 17 1481-1489. (https://doi.org/10.1038/nm.2513)

Elovaris RA, Fitzgerald PCE, Bitarafan V, Ullrich SS, Horowitz M \& Feinle-Bisset C 2019 Intraduodenal administration of L-valine has no effect on antropyloroduodenal pressures, plasma cholecystokinin concentrations or energy intake in healthy, lean men. Nutrients $\mathbf{1 1}$ E99. (https://doi.org/10.3390/nu11010099)

Fei YJ, Kanai Y, Nussberger S, Ganapathy V, Leibach FH, Romero MF, Singh SK, Boron WF \& Hediger MA 1994 Expression cloning of a mammalian proton-coupled oligopeptide transporter. Nature 368 563-566. (https://doi.org/10.1038/368563a0)

Fellows R, Denizot J, Stellato C, Cuomo A, Jain P, Stoyanova E, Balazsi S, Hajnady Z, Liebert A, Kazakevych J, et al. 2018 Microbiota derived short chain fatty acids promote histone crotonylation in the colon through histone deacetylases. Nature Communications 9 105. (https:// doi.org/10.1038/s41467-017-02651-5)

Fothergill LJ, Callaghan B, Hunne B, Bravo DM \& Furness JB 2017 Costorage of enteroendocrine hormones evaluated at the cell and subcellular levels in male mice. Endocrinology 158 2113-2123. (https://doi.org/10.1210/en.2017-00243)

Fried M, Schwizer W, Beglinger C, Keller U, Jansen JB \& Lamers CB 1991 Physiological role of cholecystokinin on postprandial insulin secretion and gastric meal emptying in man. Studies with the cholecystokinin receptor antagonist loxiglumide. Diabetologia 34 721-726. (https://doi.org/10.1007/bf00401517)

Fujita Y, Wideman RD, Asadi A, Yang GK, Baker R, Webber T, Zhang T, Wang R, Ao Z, Warnock GL, et al. 2010 Glucose-dependent insulinotropic polypeptide is expressed in pancreatic islet alpha-cells and promotes insulin secretion. Gastroenterology 138 1966-1975. (https://doi.org/10.1053/j.gastro.2010.01.049)

Gerspach AC, Steinert RE, Schonenberger L, Graber-Maier A \& Beglinger C 2011 The role of the gut sweet taste receptor in regulating GLP-1, PYY, and CCK release in humans. American Journal of Physiology: Endocrinology and Metabolism 301 E317-E325. (https://doi. org/10.1152/ajpendo.00077.2011)

Getty-Kaushik L, Song DH, Boylan MO, Corkey BE \& Wolfe MM 2006 Glucose-dependent insulinotropic polypeptide modulates adipocyte lipolysis and reesterification. Obesity 14 1124-1131. (https://doi. org/10.1038/oby.2006.129)

Glatzle J, Wang Y, Adelson DW, Kalogeris TJ, Zittel TT, Tso P, Wei JY \& Raybould HE 2003 Chylomicron components activate duodenal

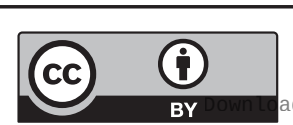

This work is licensed under a Creative Commons Attribution 4.0 International License. 
vagal afferents via a cholecystokinin A receptor-mediated pathway to inhibit gastric motor function in the rat. Journal of Physiology $\mathbf{5 5 0}$ 657-664. (https://doi.org/10.1113/jphysiol.2003.041673)

Goldspink DA, Lu VB, Billing LJ, Larraufie P, Tolhurst G, Gribble FM \& Reimann F 2018 Mechanistic insights into the detection of free fatty and bile acids by ileal glucagon-like peptide- 1 secreting cells. Molecular Metabolism 7 90-101. (https://doi.org/10.1016/j. molmet.2017.11.005)

Gorboulev V, Schurmann A, Vallon V, Kipp H, Jaschke A, Klessen D, Friedrich A, Scherneck S, Rieg T, Cunard R, et al. $2012 \mathrm{Na}(+)$-D-glucose cotransporter SGLT1 is pivotal for intestinal glucose absorption and glucose-dependent incretin secretion. Diabetes 61 187-196. (https:// doi.org/10.2337/db11-1029)

Grasset E, Puel A, Charpentier J, Collet X, Christensen JE, Terce F \& Burcelin R 2017 A specific gut microbiota dysbiosis of Type 2 diabetic mice induces GLP-1 resistance through an enteric NO-dependent and gut-brain axis mechanism. Cell Metabolism 25 1075.e5-1090.e5. (https://doi.org/10.1016/j.cmet.2017.04.013)

Greiner T \& Backhed F 2011 Effects of the gut microbiota on obesity and glucose homeostasis. Trends in Endocrinology and Metabolism 22 117-123. (https://doi.org/10.1016/j.tem.2011.01.002)

Gribble FM \& Reimann F 2016 Enteroendocrine cells: chemosensors in the intestinal epithelium. Annual Review of Physiology 78 277-299. (https://doi.org/10.1146/annurev-physiol-021115-105439)

Grider JR 1994 Role of cholecystokinin in the regulation of gastrointestinal motility. Journal of Nutrition 124 1334S-1339S. (https://doi.org/10.1093/jn/124.suppl_8.1334S)

Hansen KB, Rosenkilde MM, Knop FK, Wellner N, Diep TA, Rehfeld JF, Andersen UB, Holst JJ \& Hansen HS 2011 2-Oleoyl glycerol is a GPR119 agonist and signals GLP-1 release in humans. Journal of Clinical Endocrinology and Metabolism 96 E1409-E1417. (https://doi. org/10.1210/jc.2011-0647)

Hansen M, Scheltema MJ, Sonne DP, Hansen JS, Sperling M, Rehfeld JF, Holst JJ, Vilsboll T \& Knop FK 2016 Effect of chenodeoxycholic acid and the bile acid sequestrant colesevelam on glucagon-like peptide-1 secretion. Diabetes, Obesity and Metabolism 18 571-580. (https://doi. org/10.1111/dom.12648)

Harach T, Pols TW, Nomura M, Maida A, Watanabe M, Auwerx J \& Schoonjans K 2012 TGR5 potentiates GLP-1 secretion in response to anionic exchange resins. Scientific Reports 2 430. (https://doi org/10.1038/srep00430)

Hellstrom PM, Naslund E, Edholm T, Schmidt PT, Kristensen J, Theodorsson E, Holst JJ \& Efendic S 2008 GLP-1 suppresses gastrointestinal motility and inhibits the migrating motor complex in healthy subjects and patients with irritable bowel syndrome. Neurogastroenterology and Motility 20 649-659. (https://doi. org/10.1111/j.1365-2982.2007.01079.x)

Iqbal J \& Hussain MM 2009 Intestinal lipid absorption. American Journal of Physiology: Endocrinology and Metabolism 296 E1183-E1194. (https:// doi.org/10.1152/ajpendo.90899.2008)

Isaacs PE, Ladas S, Forgacs IC, Dowling RH, Ellam SV, Adrian TE \& Bloom SR 1987 Comparison of effects of ingested medium- and long-chain triglyceride on gallbladder volume and release of cholecystokinin and other gut peptides. Digestive Diseases and Sciences 32 481-486. (https://doi.org/10.1007/bf01296030)

Iwasaki K, Harada N, Sasaki K, Yamane S, Iida K, Suzuki K, Hamasaki A, Nasteska D, Shibue K, Joo E, et al. 2015 Free fatty acid receptor GPR120 is highly expressed in enteroendocrine $\mathrm{K}$ cells of the upper small intestine and has a critical role in GIP secretion after fat ingestion. Endocrinology 156 837-846. (https://doi.org/10.1210/en.2014-1653)

Jang HJ, Kokrashvili Z, Theodorakis MJ, Carlson OD, Kim BJ, Zhou J, Kim HH, Xu X, Chan SL, Juhaszova M, et al. 2007 Gut-expressed gustducin and taste receptors regulate secretion of glucagon-like peptide-1. PNAS 104 15069-15074. (https://doi.org/10.1073/ pnas.0706890104)

Jiang C, Xie C, Lv Y, Li J, Krausz KW, Shi J, Brocker CN, Desai D, Amin SG, Bisson WH, et al. 2015 Intestine-selective farnesoid X receptor inhibition improves obesity-related metabolic dysfunction. Nature Communications 6 10166. (https://doi.org/10.1038/ ncomms10166)

Jin H, Cai L, Lee K, Chang TM, Li P, Wagner D \& Chey WY 1993 A physiological role of peptide YY on exocrine pancreatic secretion in rats. Gastroenterology 105 208-215. (https://doi.org/10.1016/00165085(93)90028-b)

Joyner K, Smith GP \& Gibbs J 1993 Abdominal vagotomy decreases the satiating potency of CCK-8 in sham and real feeding. American Journal of Physiology 264 R912-R916. (https://doi.org/10.1152/ ajpregu.1993.264.5.R912)

Jun LS, Millican RL, Hawkins ED, Konkol DL, Showalter AD, Christe ME, Michael MD \& Sloop KW 2015 Absence of glucagon and insulin action reveals a role for the GLP-1 receptor in endogenous glucose production. Diabetes 64 819-827. (https://doi.org/10.2337/db14-1052)

Kahles F, Meyer C, Mollmann J, Diebold S, Findeisen HM, Lebherz C, Trautwein C, Koch A, Tacke F, Marx N, et al. 2014 GLP-1 secretion is increased by inflammatory stimuli in an IL-6-dependent manner, leading to hyperinsulinemia and blood glucose lowering. Diabetes 63 3221-3229. (https://doi.org/10.2337/db14-0100)

Keating DJ \& Spencer NJ 2010 Release of 5-hydroxytryptamine from the mucosa is not required for the generation or propagation of colonic migrating motor complexes. Gastroenterology 138 659.e2-670.e2. (https://doi.org/10.1053/j.gastro.2009.09.020)

Keller J \& Layer P 2005 Human pancreatic exocrine response to nutrients in health and disease. Gut $\mathbf{5 4}$ (Supplement 6) vi1-vi28. (https://doi. org/10.1136/gut.2005.065946)

Keller J, Trautmann ME, Haber H, Tham LS, Hunt T, Mace K \& Linnebjerg H 2012 Effect of exenatide on cholecystokinin-induced gallbladder emptying in fasting healthy subjects. Regulatory Peptides 179 77-83. (https://doi.org/10.1016/j.regpep.2012.08.005)

Kiefer FW, Zeyda M, Gollinger K, Pfau B, Neuhofer A, Weichhart T, Saemann MD, Geyeregger R, Schlederer M, Kenner L, et al. 2010 Neutralization of osteopontin inhibits obesity-induced inflammation and insulin resistance. Diabetes 59 935-946. (https://doi.org/10.2337/ db09-0404)

Kim H, Toyofuku Y, Lynn FC, Chak E, Uchida T, Mizukami H, Fujitani Y, Kawamori R, Miyatsuka T, Kosaka Y, et al. 2010 Serotonin regulates pancreatic beta cell mass during pregnancy. Nature Medicine 16 804-808. (https://doi.org/10.1038/nm.2173)

Koide M, Okabayashi Y \& Otsuki M 1993 Role of endogenous bile on basal and postprandial CCK release in humans. Digestive Diseases and Sciences 38 1284-1290. (https://doi.org/10.1007/bf01296080)

Kokrashvili Z, Mosinger B \& Margolskee RF 2009 T1r3 and alphagustducin in gut regulate secretion of glucagon-like peptide-1. Annals of the New York Academy of Sciences 1170 91-94. (https://doi. org/10.1111/j.1749-6632.2009.04485.x)

Koop I, Fellgiebel A, Koop H, Schafmayer A \& Arnold R 1988 Effect of cholestyramine on plasma cholecystokinin and pancreatic polypeptide levels, and exocrine pancreatic secretion. European Journal of Clinical Investigation 18 517-523. (https://doi. org/10.1111/j.1365-2362.1988.tb01050.x)

Kreuch D, Keating DJ, Wu T, Horowitz M, Rayner CK \& Young RL 2018 Gut mechanisms linking intestinal sweet sensing to glycemic control. Frontiers in Endocrinology 9 741. (https://doi.org/10.3389/ fendo.2018.00741)

Kuhre RE, Albrechtsen NW, Windelov JA, Svendsen B, Hartmann B \& Holst JJ 2014a GLP-1 amidation efficiency along the length of the intestine in mice, rats and pigs and in GLP-1 secreting cell lines. Peptides 55 52-57. (https://doi.org/10.1016/j.peptides.2014.01.020)

Kuhre RE, Gribble FM, Hartmann B, Reimann F, Windelov JA, Rehfeld JF \& Holst JJ $2014 b$ Fructose stimulates GLP-1 but not GIP secretion in mice, rats, and humans. American Journal of Physiology: Gastrointestinal and Liver Physiology 306 G622-G630. (https://doi.org/10.1152/ ajpgi.00372.2013)

Kuhre RE, Wewer Albrechtsen NJ, Larsen O, Jepsen SL, Balk-Moller E, Andersen DB, Deacon CF, Schoonjans K, Reimann F, Gribble FM,

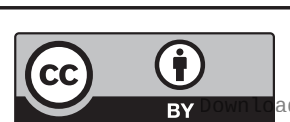

This work is licensed under a Creative Commons Attribution 4.0 International License. 
et al. 2018 Bile acids are important direct and indirect regulators of the secretion of appetite- and metabolism-regulating hormones from the gut and pancreas. Molecular Metabolism 11 84-95. (https://doi. org/10.1016/j.molmet.2018.03.007)

Lan H, Lin HV, Wang CF, Wright MJ, Xu S, Kang L, Juhl K, Hedrick JA \& Kowalski TJ 2012 Agonists at GPR119 mediate secretion of GLP-1 from mouse enteroendocrine cells through glucose-independent pathways. British Journal of Pharmacology 165 2799-2807. (https://doi. org/10.1111/j.1476-5381.2011.01754.x)

Larraufie P, Martin-Gallausiaux C, Lapaque N, Dore J, Gribble FM, Reimann F \& Blottiere HM 2018 SCFAs strongly stimulate PYY production in human enteroendocrine cells. Scientific Reports 874. (https://doi.org/10.1038/s41598-017-18259-0)

Lebrun LJ, Lenaerts K, Kiers D, Pais de Barros JP, Le Guern N, Plesnik J, Thomas C, Bourgeois T, Dejong CHC, Kox M, et al. 2017 Enteroendocrine L cells sense LPS after gut barrier injury to enhance GLP-1 secretion. Cell Reports 21 1160-1168. (https://doi. org/10.1016/j.celrep.2017.10.008)

Lefebvre P, Cariou B, Lien F, Kuipers F \& Staels B 2009 Role of bile acids and bile acid receptors in metabolic regulation. Physiological Reviews 89 147-191. (https://doi.org/10.1152/physrev.00010.2008)

Li Y, Hao Y, Zhu J \& Owyang C 2000 Serotonin released from intestinal enterochromaffin cells mediates luminal non-cholecystokininstimulated pancreatic secretion in rats. Gastroenterology 118 1197-1207. (https://doi.org/10.1016/s0016-5085(00)70373-8)

Li Y, Wu XY, Zhu JX \& Owyang C 2001 Intestinal serotonin acts as paracrine substance to mediate pancreatic secretion stimulated by luminal factors. American Journal of Physiology: Gastrointestinal and Liver Physiology 281 G916-G923. (https://doi.org/10.1152/ajpgi.2001.281.4.G916)

Li Y, Schnabl K, Gabler SM, Willershäuser M, Reber J, Karlas A, Laurila S, Lahesmaa M, U Din M, Bast-Habersbrunner A, et al. 2018 Secretinactivated brown fat mediates prandial thermogenesis to induce satiation. Cell 175 1561.e12-1574.e12. (https://doi.org/10.1016/j. cell.2018.10.016)

Li Z, Yu R, Yin W, Qin Y, Ma L, Mulholland M \& Zhang W 2019 MTOR signaling in X/A-like cells contributes to lipid homeostasis in mice. Hepatology 69 860-875. (https://doi.org/10.1002/hep.30229)

Liddle RA, Rushakoff RJ, Morita ET, Beccaria L, Carter JD \& Goldfine ID 1988 Physiological role for cholecystokinin in reducing postprandial hyperglycemia in humans. Journal of Clinical Investigation 81 16751681. (https://doi.org/10.1172/JCI113505)

Lin Y, Liang Z, He L, Yang M, Liu D, Gu HF, Liu H, Zhu Z, Zheng H, Li L, et al. 2019 Gut ghrelin regulates hepatic glucose production and insulin signaling via a gut-brain-liver pathway. Cell Communication and Signaling 17 8. (https://doi.org/10.1186/ s12964-019-0321-y)

Liou AP, Chavez DI, Espero E, Hao S, Wank SA \& Raybould HE $2011 a$ Protein hydrolysate-induced cholecystokinin secretion from enteroendocrine cells is indirectly mediated by the intestinal oligopeptide transporter PepT1. American Journal of Physiology: Gastrointestinal and Liver Physiology 300 G895-G902. (https://doi. org/10.1152/ajpgi.00521.2010)

Liou AP, Lu X, Sei Y, Zhao X, Pechhold S, Carrero RJ, Raybould HE \& Wank S $2011 b$ The G-protein-coupled receptor GPR40 directly mediates longchain fatty acid-induced secretion of cholecystokinin. Gastroenterology 140 903-912. (https://doi.org/10.1053/j.gastro.2010.10.012)

Liou AP, Sei Y, Zhao X, Feng J, Lu X, Thomas C, Pechhold S, Raybould HE \& Wank SA 2011c The extracellular calcium-sensing receptor is required for cholecystokinin secretion in response to L-phenylalanine in acutely isolated intestinal I cells. American Journal of Physiology: Gastrointestinal and Liver Physiology 300 G538-G546. (https://doi. org/10.1152/ajpgi.00342.2010)

Lu WJ, Yang Q, Yang L, Lee D, D’Alessio D \& Tso P 2012 Chylomicron formation and secretion is required for lipid-stimulated release of incretins GLP-1 and GIP. Lipids 47 571-580. (https://doi.org/10.1007/ s11745-011-3650-1)
Lumsden AL, Martin AM, Sun EW, Schober G, Isaacs NJ, Pezos N, Wattchow DA, de Fontgalland D, Rabbitt P, Hollington P, et al. 2019 Sugar responses of human enterochromaffin cells depend on gut region, sex, and body mass. Nutrients 11234 . (https://doi org/10.3390/nu11020234)

Lund ML, Egerod KL, Engelstoft MS, Dmytriyeva O, Theodorsson E, Patel BA \& Schwartz TW 2018 Enterochromaffin 5-HT cells - a major target for GLP-1 and gut microbial metabolites. Molecular Metabolism 11 70-83. (https://doi.org/10.1016/j.molmet.2018.03.004)

Mace OJ, Schindler M \& Patel S 2012 The regulation of K- and L-cell activity by GLUT2 and the calcium-sensing receptor CasR in rat small intestine. Journal of Physiology 590 2917-2936. (https://doi org/10.1113/jphysiol.2011.223800)

Maciel MG, Beserra BTS, Oliveira FCB, Ribeiro CM, Coelho MS, Neves FAR \& Amato AA 2018 The effect of glucagon-like peptide 1 and glucagonlike peptide 1 receptor agonists on energy expenditure: a systematic review and meta-analysis. Diabetes Research and Clinical Practice 142 222-235. (https://doi.org/10.1016/j.diabres.2018.05.034)

Maljaars PW, Peters HP, Mela DJ \& Masclee AA 2008 Ileal brake: a sensible food target for appetite control. A review. Physiology and Behavior 95 271-281. (https://doi.org/10.1016/j.physbeh.2008.07.018)

Mandoe MJ, Hansen KB, Windelov JA, Knop FK, Rehfeld JF, Rosenkilde MM, Holst JJ \& Hansen HS 2018 Comparing olive oil and C4-dietary oil, a prodrug for the GPR119 agonist, 2-oleoyl glycerol, less energy intake of the latter is needed to stimulate incretin hormone secretion in overweight subjects with type 2 diabetes. Nutrition and Diabetes 8 2. (https://doi.org/10.1038/s41387-017-0011-z)

Mao Z, Yang Q, Yin W, Su W, Lin H, Feng M, Pan K, Yin Y \& Zhang W 2019 ETV5 regulates GOAT/ghrelin system in an mTORC1-dependent manner. Molecular and Cellular Endocrinology 485 72-80. (https://doi. org/10.1016/j.mce.2019.02.003)

Marchetti P, Lupi R, Bugliani M, Kirkpatrick CL, Sebastiani G, Grieco FA, Del Guerra S, D'Aleo V, Piro S, Marselli L, et al. 2012 A local glucagonlike peptide 1 (GLP-1) system in human pancreatic islets. Diabetologia 55 3262-3272. (https://doi.org/10.1007/s00125-012-2716-9)

Marina AL, Utzschneider KM, Wright LA, Montgomery BK, Marcovina SM \& Kahn SE 2012 Colesevelam improves oral but not intravenous glucose tolerance by a mechanism independent of insulin sensitivity and beta-cell function. Diabetes Care 35 1119-1125. (https://doi. org/10.2337/dc11-2050)

Martin AM, Lumsden AL, Young RL, Jessup CF, Spencer NJ \& Keating DJ $2017 a$ The nutrient-sensing repertoires of mouse enterochromaffin cells differ between duodenum and colon. Neurogastroenterology and Motility 29 e13046. (https://doi.org/10.1111/nmo.13046)

Martin AM, Lumsden AL, Young RL, Jessup CF, Spencer NJ \& Keating DJ $2017 b$ Regional differences in nutrient-induced secretion of gut serotonin. Physiological Reports 5 e13199. (https://doi.org/10.14814/ phy2.13199)

Martin AM, Sun EW, Rogers GB \& Keating DJ 2019 The influence of the gut microbiome on host metabolism through the regulation of gut hormone release. Frontiers in Physiology 10 428. (https://doi. org/10.3389/fphys.2019.00428)

Moss CE, Glass LL, Diakogiannaki E, Pais R, Lenaghan C, Smith DM, Wedin M, Bohlooly M, Gribble FM \& Reimann F 2016 Lipid derivatives activate GPR119 and trigger GLP-1 secretion in primary murine L-cells. Peptides 77 16-20. (https://doi.org/10.1016/j. peptides.2015.06.012)

Muller TD, Nogueiras R, Andermann ML, Andrews ZB, Anker SD, Argente J, Batterham RL, Benoit SC, Bowers CY, Broglio F, et al. 2015 Ghrelin. Molecular Metabolism 4 437-460. (https://doi.org/10.1016/j. molmet.2015.03.005)

Murphy KG \& Bloom SR 2004 Gut hormones in the control of appetite. Experimental Physiology 89 507-516. (https://doi.org/10.1113/ expphysiol.2004.027789)

Nakatani Y, Maeda M, Matsumura M, Shimizu R, Banba N, Aso Y, Yasu T \& Harasawa H 2017 Effect of GLP-1 receptor agonist on

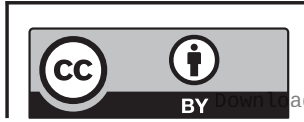

This work is licensed under a Creative Commons Attribution 4.0 International License. 
gastrointestinal tract motility and residue rates as evaluated by capsule endoscopy. Diabetes and Metabolism 43 430-437. (https://doi. org/10.1016/j.diabet.2017.05.009)

Nohr MK, Pedersen MH, Gille A, Egerod KL, Engelstoft MS, Husted AS, Sichlau RM, Grunddal KV, Poulsen SS, Han S, et al. 2013 GPR41/ FFAR3 and GPR43/FFAR2 as cosensors for short-chain fatty acids in enteroendocrine cells vs FFAR3 in enteric neurons and FFAR2 in enteric leukocytes. Endocrinology 154 3552-3564. (https://doi. org/10.1210/en.2013-1142)

Offermanns S 2014 Free fatty acid (FFA) and hydroxy carboxylic acid (HCA) receptors. Annual Review of Pharmacology and Toxicology 54 407-434. (https://doi.org/10.1146/annurevpharmtox-011613-135945)

Parker HE, Habib AM, Rogers GJ, Gribble FM \& Reimann F 2009 Nutrientdependent secretion of glucose-dependent insulinotropic polypeptide from primary murine K cells. Diabetologia 52 289-298. (https://doi. org/10.1007/s00125-008-1202-x)

Parker HE, Adriaenssens A, Rogers G, Richards P, Koepsell H, Reimann F \& Gribble FM 2012 Predominant role of active versus facilitative glucose transport for glucagon-like peptide-1 secretion. Diabetologia 55 2445-2455. (https://doi.org/10.1007/s00125-012-2585-2)

Pichette J, Fynn-Sackey N \& Gagnon J 2017 Hydrogen sulfide and sulfate prebiotic stimulates the secretion of GLP-1 and improves glycemia in male mice. Endocrinology 158 3416-3425. (https://doi.org/10.1210/ en.2017-00391)

Pierre JF, Li Y, Gomes CK, Rao P, Chang EB \& Yin DP 2019 Bile diversion improves metabolic phenotype dependent on farnesoid $\mathrm{X}$ receptor (FXR). Obesity 27 803-812. (https://doi.org/10.1002/oby.22440)

Plamboeck A, Veedfald S, Deacon CF, Hartmann B, Wettergren A, Svendsen LB, Meisner S, Hovendal C, Vilsboll T, Knop FK, et al. 2013 The effect of exogenous GLP-1 on food intake is lost in male truncally vagotomized subjects with pyloroplasty. American Journal of Physiology: Gastrointestinal and Liver Physiology 304 G1117-G1127. (https://doi.org/10.1152/ajpgi.00035.2013)

Psichas A, Larraufie PF, Goldspink DA, Gribble FM \& Reimann F 2017 Chylomicrons stimulate incretin secretion in mouse and human cells. Diabetologia 60 2475-2485. (https://doi.org/10.1007/s00125-0174420-2)

Rayner CK, Samsom M, Jones KL \& Horowitz M 2001 Relationships of upper gastrointestinal motor and sensory function with glycemic control. Diabetes Care 24 371-381. (https://doi.org/10.2337/diacare.24.2.371)

Reigstad CS, Salmonson CE, Rainey 3rd JF, Szurszewski JH, Linden DR, Sonnenburg JL, Farrugia G \& Kashyap PC 2015 Gut microbes promote colonic serotonin production through an effect of short-chain fatty acids on enterochromaffin cells. FASEB Journal 29 1395-1403. (https://doi.org/10.1096/fj.14-259598)

Reimann F, Habib AM, Tolhurst G, Parker HE, Rogers GJ \& Gribble FM 2008 Glucose sensing in L cells: a primary cell study. Cell Metabolism 8 532-539. (https://doi.org/10.1016/j.cmet.2008.11.002)

Rozenblit-Susan S, Chapnik N \& Froy O 2016 Metabolic effect of fluvoxamine in mouse peripheral tissues. Molecular and Cellular Endocrinology 424 12-22. (https://doi.org/10.1016/j.mce.2016.01.009)

Rudenko O, Shang J, Munk A, Ekberg JP, Petersen N, Engelstoft MS, Egerod KL, Hjorth SA, Wu M, Feng Y, et al. 2019 The aromatic amino acid sensor GPR142 controls metabolism through balanced regulation of pancreatic and gut hormones. Molecular Metabolism 19 49-64. (https://doi.org/10.1016/j.molmet.2018.10.012)

Sakata I, Park WM, Walker AK, Piper PK, Chuang JC, Osborne-Lawrence S \& Zigman JM 2012 Glucose-mediated control of ghrelin release from primary cultures of gastric mucosal cells. American Journal of Physiology: Endocrinology and Metabolism 302 E1300-E1310. (https:// doi.org/10.1152/ajpendo.00041.2012)

Saltiel MY, Kuhre RE, Christiansen CB, Eliasen R, Conde-Frieboes KW Rosenkilde MM \& Holst JJ 2017 Sweet taste receptor activation in the gut is of limited importance for glucose-stimulated GLP-1 and GIP secretion. Nutrients 9 E418. (https://doi.org/10.3390/nu9040418)
Sankoda A, Harada N, Iwasaki K, Yamane S, Murata Y, Shibue K, Thewjitcharoen Y, Suzuki K, Harada T, Kanemaru Y, et al. 2017 Long-chain free fatty acid receptor GPR120 mediates oil-induced GIP secretion through CCK in male mice. Endocrinology 158 1172-1180. (https://doi.org/10.1210/en.2017-00090)

Schaller G, Schmidt A, Pleiner J, Woloszczuk W, Wolzt M \& Luger A 2003 Plasma ghrelin concentrations are not regulated by glucose or insulin: a double-blind, placebo-controlled crossover clamp study. Diabetes $\mathbf{5 2}$ 16-20. (https://doi.org/10.2337/diabetes.52.1.16)

Sherwin RS 1980 Role of the liver in glucose homeostasis. Diabetes Care $\mathbf{3}$ 261-265. (https://doi.org/10.2337/diacare.3.2.261)

Shi YC, Loh K, Bensellam M, Lee K, Zhai L, Lau J, Cantley J, Luzuriaga J, Laybutt DR \& Herzog H 2015 Pancreatic PYY is critical in the control of insulin secretion and glucose homeostasis in female mice. Endocrinology 156 3122-3136. (https://doi.org/10.1210/en.2015-1168)

Smith EP, An Z, Wagner C, Lewis AG, Cohen EB, Li B, Mahbod P, Sandoval D, Perez-Tilve D, Tamarina N, et al. 2014 The role of beta cell glucagon-like peptide- 1 signaling in glucose regulation and response to diabetes drugs. Cell Metabolism 19 1050-1057. (https:// doi.org/10.1016/j.cmet.2014.04.005)

Smits MM, Tonneijck L, Muskiet MH, Hoekstra T, Kramer MH, Diamant M, Nieuwdorp M, Groen AK, Cahen DL \& van Raalte DH 2016 Biliary effects of liraglutide and sitagliptin, a 12-week randomized placebo-controlled trial in type 2 diabetes patients. Diabetes, Obesity and Metabolism 18 1217-1225. (https://doi. org/10.1111/dom.12748)

Smushkin G, Sathananthan M, Piccinini F, Dalla Man C, Law JH, Cobelli C, Zinsmeister AR, Rizza RA \& Vella A 2013 The effect of a bile acid sequestrant on glucose metabolism in subjects with type 2 diabetes. Diabetes 62 1094-1101. (https://doi.org/10.2337/db12-0923)

Sommer CA \& Mostoslavsky G 2014 RNA-Seq analysis of enteroendocrine cells reveals a role for FABP5 in the control of GIP secretion. Molecular Endocrinology 28 1855-1865. (https://doi.org/10.1210/me.2014-1194)

Song Y, Koehler JA, Baggio LL, Powers AC, Sandoval DA \& Drucker DJ 2019 Gut-proglucagon-derived peptides are essential for regulating glucose homeostasis in mice. Cell Metabolism 30 976.e3-986.e3. (https://doi.org/10.1016/j.cmet.2019.08.009)

Steinert RE, Gerspach AC, Gutmann H, Asarian L, Drewe J \& Beglinger C 2011 The functional involvement of gut-expressed sweet taste receptors in glucose-stimulated secretion of glucagon-like peptide-1 (GLP-1) and peptide YY (PYY). Clinical Nutrition 30 524-532. (https:// doi.org/10.1016/j.clnu.2011.01.007)

Steinert RE, Landrock MF, Ullrich SS, Standfield S, Otto B, Horowitz M \& Feinle-Bisset C 2015 Effects of intraduodenal infusion of the branched-chain amino acid leucine on ad libitum eating, gut motor and hormone functions, and glycemia in healthy men. American Journal of Clinical Nutrition 102 820-827. (https://doi.org/10.3945/ ajcn.115.114488)

Stern JH, Rutkowski JM \& Scherer PE 2016 Adiponectin, leptin, and fatty acids in the maintenance of metabolic homeostasis through adipose tissue crosstalk. Cell Metabolism 23 770-784. (https://doi. org/10.1016/j.cmet.2016.04.011)

Sumara G, Sumara O, Kim JK \& Karsenty G 2012 Gut-derived serotonin is a multifunctional determinant to fasting adaptation. Cell Metabolism 16 588-600. (https://doi.org/10.1016/j.cmet.2012.09.014)

Sun EW, de Fontgalland D, Rabbitt P, Hollington P, Sposato L, Due SL, Wattchow DA, Rayner CK, Deane AM, Young RL, et al. 2017 Mechanisms controlling glucose-induced GLP-1 secretion in human small intestine. Diabetes 66 2144-2149. (https://doi.org/10.2337/db17-0058)

Sun EWL, Martin AM, Young RL \& Keating DJ 2018 The regulation of peripheral metabolism by gut-derived hormones. Frontiers in Endocrinology 9 754. (https://doi.org/10.3389/fendo.2018.00754)

Svendsen B, Larsen O, Gabe MBN, Christiansen CB, Rosenkilde MM, Drucker DJ \& Holst JJ 2018 Insulin secretion depends on intra-islet glucagon signaling. Cell Reports 25 1127.e2-1134.e2. (https://doi. org/10.1016/j.celrep.2018.10.018)

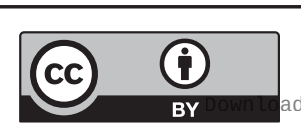

This work is licensed under a Creative Commons Attribution 4.0 International License. 
Sykaras AG, Demenis C, Case RM, McLaughlin JT \& Smith CP 2012 Duodenal enteroendocrine I-cells contain mRNA transcripts encoding key endocannabinoid and fatty acid receptors. PLOS ONE 7 e42373. (https://doi.org/10.1371/journal.pone.0042373)

Tatemoto K 1982 Isolation and characterization of peptide YY (PYY), a candidate gut hormone that inhibits pancreatic exocrine secretion. PNAS 79 2514-2518. (https://doi.org/10.1073/pnas.79.8.2514)

Thazhath SS, Marathe CS, Wu T, Chang J, Khoo J, Kuo P, Checklin HL, Bound MJ, Rigda RS, Crouch B, et al. 2016 The glucagon-like peptide 1 receptor agonist exenatide inhibits small intestinal motility, flow, transit, and absorption of glucose in healthy subjects and patients with type 2 diabetes: a randomized controlled trial. Diabetes $\mathbf{6 5}$ 269-275. (https://doi.org/10.2337/db15-0893)

Theander-Carrillo C, Wiedmer P, Cettour-Rose P, Nogueiras R, PerezTilve D, Pfluger P, Castaneda TR, Muzzin P, Schurmann A, Szanto I, et al. 2006 Ghrelin action in the brain controls adipocyte metabolism. Journal of Clinical Investigation 116 1983-1993. (https://doi. org/10.1172/JCI25811)

Thomas C, Gioiello A, Noriega L, Strehle A, Oury J, Rizzo G, Macchiarulo A, Yamamoto H, Mataki C, Pruzanski M, et al. 2009 TGR5-mediated bile acid sensing controls glucose homeostasis. Cell Metabolism 10 167-177. (https://doi.org/10.1016/j.cmet.2009.08.001)

Tian M, Heng J, Song H, Zhang Y, Chen F, Guan W \& Zhang S 2019 Branched chain amino acids stimulate gut satiety hormone cholecystokinin secretion through activation of the umami taste receptor T1R1/T1R3 using an in vitro porcine jejunum model. Food and Function 10 3356-3367. (https://doi.org/10.1039/c9fo00228f)

Tolhurst G, Heffron H, Lam YS, Parker HE, Habib AM, Diakogiannaki E, Cameron J, Grosse J, Reimann F \& Gribble FM 2012 Short-chain fatty acids stimulate glucagon-like peptide- 1 secretion via the G-protein-coupled receptor FFAR2. Diabetes 61 364-371. (https://doi. org/10.2337/db11-1019)

Trabelsi MS, Daoudi M, Prawitt J, Ducastel S, Touche V, Sayin SI, Perino A, Brighton CA, Sebti Y, Kluza J, et al. 2015 Farnesoid X receptor inhibits glucagon-like peptide- 1 production by enteroendocrine L cells. Nature Communications 6 7629. (https://doi.org/10.1038/ncomms8629)

Turnbaugh PJ, Ley RE, Mahowald MA, Magrini V, Mardis ER \& Gordon JI 2006 An obesity-associated gut microbiome with increased capacity for energy harvest. Nature 444 1027-1031. (https://doi.org/10.1038/ nature05414)

Turnbaugh PJ, Hamady M, Yatsunenko T, Cantarel BL, Duncan A, Ley RE, Sogin ML, Jones WJ, Roe BA, Affourtit JP, et al. 2009 A core gut microbiome in obese and lean twins. Nature 457 480-484. (https:// doi.org/10.1038/nature07540)

Uchida-Kitajima S, Yamauchi T, Takashina Y, Okada-Iwabu M, Iwabu M, Ueki K \& Kadowaki T 2008 5-Hydroxytryptamine 2A receptor signaling cascade modulates adiponectin and plasminogen activator inhibitor 1 expression in adipose tissue. FEBS Letters 582 3037-3044. (https://doi.org/10.1016/j.febslet.2008.07.044)

Vahl TP, Tauchi M, Durler TS, Elfers EE, Fernandes TM, Bitner RD, Ellis KS, Woods SC, Seeley RJ, Herman JP, et al. 2007 Glucagon-like peptide-1 (GLP-1) receptors expressed on nerve terminals in the portal vein mediate the effects of endogenous GLP-1 on glucose tolerance in rats. Endocrinology 148 4965-4973. (https://doi.org/10.1210/en.2006-0153)

Waldecker M, Kautenburger T, Daumann H, Busch C \& Schrenk D 2008 Inhibition of histone-deacetylase activity by short-chain fatty acids and some polyphenol metabolites formed in the colon. Journal of Nutritional Biochemistry 19 587-593. (https://doi.org/10.1016/j. jnutbio.2007.08.002)

Wellendorph P, Hansen KB, Balsgaard A, Greenwood JR, Egebjerg J \& Brauner-Osborne H 2005 Deorphanization of GPRC6A: a promiscuous

L-alpha-amino acid receptor with preference for basic amino acids. Molecular Pharmacology 67 589-597. (https://doi.org/10.1124/ mol.104.007559)

Williams DL, Cummings DE, Grill HJ \& Kaplan JM 2003 Meal-related ghrelin suppression requires postgastric feedback. Endocrinology 144 2765-2767. (https://doi.org/10.1210/en.2003-0381)

Wu T, Zhao BR, Bound MJ, Checklin HL, Bellon M, Little TJ, Young RL, Jones KL, Horowitz M \& Rayner CK 2012 Effects of different sweet preloads on incretin hormone secretion, gastric emptying, and postprandial glycemia in healthy humans. American Journal of Clinical Nutrition 95 78-83. (https://doi.org/10.3945/ajcn.111.021543)

Wu T, Bound MJ, Standfield SD, Gedulin B, Jones KL, Horowitz M \& Rayner CK 2013a Effects of rectal administration of taurocholic acid on glucagon-like peptide- 1 and peptide YY secretion in healthy humans. Diabetes, Obesity and Metabolism 15 474-477. (https://doi. org/10.1111/dom.12043)

Wu T, Bound MJ, Standfield SD, Jones KL, Horowitz M \& Rayner CK $2013 b$ Effects of taurocholic acid on glycemic, glucagon-like peptide-1, and insulin responses to small intestinal glucose infusion in healthy humans. Journal of Clinical Endocrinology and Metabolism 98 E718-E722. (https://doi.org/10.1210/jc.2012-3961)

Wynne K, Stanley S, McGowan B \& Bloom S 2005 Appetite control. Journal of Endocrinology 184 291-318. (https://doi.org/10.1677/ joe.1.05866)

Xu G, Li Y, An W, Li S, Guan Y, Wang N, Tang C, Wang X, Zhu Y, Li X, et al. 2009 Gastric mammalian target of rapamycin signaling regulates ghrelin production and food intake. Endocrinology 150 3637-3644. (https://doi.org/10.1210/en.2009-0372)

Xu G, Wang Z, Li Y, Li Z, Tang H, Zhao J, Xiang X, Ding L, Ma L, Yuan F, et al. 2012 Ghrelin contributes to derangements of glucose metabolism induced by rapamycin in mice. Diabetologia 55 18131823. (https://doi.org/10.1007/s00125-012-2509-1)

Xu G, Li Z, Ding L, Tang H, Guo S, Liang H, Wang H \& Zhang W 2015 Intestinal mTOR regulates GLP-1 production in mouse L cells. Diabetologia 58 1887-1897. (https://doi.org/10.1007/s00125-0153632-6)

Yano JM, Yu K, Donaldson GP, Shastri GG, Ann P, Ma L, Nagler CR, Ismagilov RF, Mazmanian SK \& Hsiao EY 2015 Indigenous bacteria from the gut microbiota regulate host serotonin biosynthesis. Cell 161 264-276. (https://doi.org/10.1016/j.cell.2015.02.047)

Young RL, Lumsden AL, Martin AM, Schober G, Pezos N, Thazhath SS, Isaacs NJ, Cvijanovic N, Sun EWL, Wu T, et al. 2018 Augmented capacity for peripheral serotonin release in human obesity. International Journal of Obesity 42 1880-1889. (https://doi. org/10.1038/s41366-018-0047-8)

Yusta B, Matthews D, Flock GB, Ussher JR, Lavoie B, Mawe GM \& Drucker DJ 2017 Glucagon-like peptide-2 promotes gallbladder refilling via a TGR5-independent, GLP-2R-dependent pathway. Molecular Metabolism 6 503-511. (https://doi.org/10.1016/j. molmet.2017.03.006)

Zarling EJ \& Ruchim MA 1987 Protein origin of the volatile fatty acids isobutyrate and isovalerate in human stool. Journal of Laboratory and Clinical Medicine 109 566-570.

Zhang X, Young RL, Bound M, Hu S, Jones KL, Horowitz M, Rayner CK \& Wu T 2019 Comparative effects of proximal and distal small intestinal glucose exposure on glycemia, incretin hormone secretion, and the incretin effect in health and Type 2 diabetes. Diabetes Care 42 520-528. (https://doi.org/10.2337/dc18-2156)

Zietek T, Rath E, Haller D \& Daniel H 2015 Intestinal organoids for assessing nutrient transport, sensing and incretin secretion. Scientific Reports 5 16831. (https://doi.org/10.1038/srep16831)

Received in final form 29 October 2019

Accepted 18 November 2019

Accepted Manuscript published online 18 November 2019

https://joe.bioscientifica.com https://doi.org/10.1530/JOE-19-0399 (c) 2020 The authors Published by Bioscientifica Ltd. Printed in Great Britain

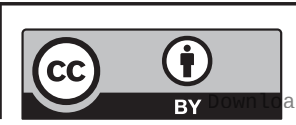

This work is licensed under a Creative Commons Attribution 4.0 International License. 